\title{
Herbal Medicinal Products from Passiflora for Anxiety: An Unexploited Potential
}

\author{
Lyca R. da Fonseca, ${ }^{1,2}$ Rafaele de A. Rodrigues, ${ }^{1,2}$ Aline de S. Ramos $\mathbb{D}^{1}{ }^{1}$ \\ Jefferson D. da Cruz, ${ }^{1,3}$ José Luiz P. Ferreira, ${ }^{1,4}$ Jefferson Rocha de A. Silva $\mathbb{D}^{5}$ \\ and Ana Claudia F. Amaral $\mathbb{D}^{1}$ \\ ${ }^{1}$ Laboratory of Medicinal Plants and Derivatives, Department of Chemistry of Natural Products, Farmanguinhos, Fiocruz, \\ Rio de Janeiro 21041-250, Brazil \\ ${ }^{2}$ Professional Postgraduate Program in Management, Research and Development in Pharmaceutical Industry, Farmanguinhos, \\ Fiocruz, Rio de Janeiro 21041-250, Brazil \\ ${ }^{3}$ Academic Postgraduate Program in Translational Research in Drugs and Medicines, Farmanguinhos, Fiocruz, \\ Rio de Janeiro 21041-250, Brazil \\ ${ }^{4}$ Faculty of Pharmacy, Fluminense Federal University, Niterói 24241-002, Brazil \\ ${ }^{5}$ Laboratory of Chromatography, Department of Chemistry, Federal University of Amazonas, Manaus 69077-000, Brazil
}

Correspondence should be addressed to Aline de S. Ramos; ramos.aline@gmail.com and Ana Claudia F. Amaral; aamaral_99@yahoo.com.br

Received 11 February 2020; Revised 12 June 2020; Accepted 27 June 2020; Published 20 July 2020

Academic Editor: Abdu Adem

Copyright (c) 2020 Lyca R. da Fonseca et al. This is an open access article distributed under the Creative Commons Attribution License, which permits unrestricted use, distribution, and reproduction in any medium, provided the original work is properly cited.

\begin{abstract}
Herbal medicines containing Passiflora species have been widely used to treat anxiety since ancient times. The species Passiflora incarnata L. is included in many Pharmacopoeias, and it is the most used species in food, cosmetic, and pharmaceutical industries. However, there are around 600 species of the genus Passiflora and probably other species that can be used safely. Thus, this article was based on a search into the uses of the main species of the genus Passiflora with anxiolytic activity and its main secondary metabolites and some pharmacological studies, patents, and registered products containing Passiflora. Furthermore, the Brazilian Regulatory Health Agency Datavisa, Medicines and Healthcare Products Regulatory Agency of the United Kingdom, and the European Medicines Agency websites were consulted. The results showed that Passiflora species have health benefits but clinical trials are still scarce. The complexity of Passiflora extracts creates challenges for the development of herbal medicines. P. incarnata is the most studied species of the genus and the most used in natural anxiolytic herbal medicine formulations. However, there are hundreds of Passiflora species potentially useful for medicinal and nutraceutical purposes that are still little explored.
\end{abstract}

\section{Introduction}

The contemporaneous tense lifestyle is responsible for the wide use of anxiolytic substances, mainly those of the benzodiazepine group. This class of synthetic drugs is one of the most prescribed antianxiety drugs in the world to treat stress and anxiety. However, many risks are associated to their use, such as dependence, abstinence syndrome, and the reduction of motor reflexes. Therefore, the use and acceptance of herbal medicines and nutraceuticals for these purposes, including
Passiflora species, have been growing among doctors and patients [1]. In vitro and in vivo studies are needed to establish the bioequivalence of herbal formulations. In the case of Passiflora formulations, the standardization can be based on the potency in animal models, such as the open arm plusmaze using rats or mice. After the isolation of the substances responsible for the anxiolytic activity, the pharmaceutical equivalence can be applied [2].

Many countries have laws regulating herbal medicinal products. Germany, that is considered the world's largest 
market for these products [3], defines herbal medicinal products as "medicinal products that exclusively contain, as active substances, one or more herbal substances, one or more herbal preparations, or one or more such herbal substances in combination with one or more such herbal preparations, according to the German Drug Law [4].” Estimates suggest that Germany spends more than 2 billion dollars on herbal medicinal products each year [3].

The Directive 2001/83/EC [5] and Directive 2004/24/EC [6] of the European Parliament of the Council of the European Union are codes for medicinal products and traditional herbal medicinal products for human use. The code defines herbal medicinal products as any medicinal product exclusively containing, as active ingredients, one or more herbal substances (whole or fragmented plants) or herbal preparations (tinctures, extracts, essential oils, etc). In the same code, traditional herbal medicinal products have simplified registration, because they can be used without prescription or monitoring treatment and the products are not harmful when used according to the instructions of the manufacture. They may be administered orally, topically, or by inhalation. The pharmacological effects or efficacy are based on long experience (at least 30 years, including at least 15 years within the European Community) but the safety of the product must be ensured, and the quality must be verified according to the European Pharmacopoeia monographs, or those in the Pharmacopoeia of a Member State [7].

The regulatory requirements for the registration of herbal medicines in Brazil are similar to those in Europe. In Brazil, these preparations are classified as herbal medicines if they are obtained only from active raw vegetal material, of which the efficacy and safety have been validated through ethnopharmacological surveys, scientific and technical documentation, or clinical evidence [8]. These products may be registered and marketed as traditional herbal medicine, if evidence of their safe and effective use has been published in scientific and technical literature, and there is evidence of continuous safe use for a minimum period of thirty years. Furthermore, they may not be used for any serious diseases; they may not contain materials in toxic concentrations; and they should not be administered by the ophthalmic or intravenous routes. The safety and efficacy of herbal medicines are based on clinical evidence, and they are characterized by consistent quality [9]. Any registrations or marketing authorizations in other countries, and the reasons for refusal of registration or marketing authorization must be stated [3]. Traditional herbal medicinal products are designed for use without the supervision of a physician in terms of diagnosis, prescription, or monitoring.

Arifin and coworkers [10] list and discuss several challenges that impact the development of a herbal medicinal product. Normally, the difficulties present in the production of a herbal medicine are related to the isolation of the active ingredient(s) and its pharmacological evidence, safety, and therapeutic efficacy. The complex nature of plants creates difficulties, and consequently, there are challenges for the development of herbal medicinal products, which is not a quick and simple process. Plant species have various phytochemicals with different characteristics, e.g., absorption, solubility that affect their bioavailability. Additionally, there are the possible unknown toxic effects, potential harmful interactions of herbal medicinal products and the lack of pharmacokinetic parameters such as gastrointestinal absorption, protein binding, and plasma clearance by the liver and kidneys, which are all important challenges to overcome to be able to produce new medicines from medicinal plants. The quality of herbal products from a technological point of view is ensured for the intermediate and finished products, using adequate production planning, appropriate production processes, and strict control of the raw materials from the plant species used. All of these cares must ultimately result in products with constant quality, efficacy, and security.

This article was based on a literature search into the widespread use of the main species of the genus Passiflora and their main secondary metabolites to treat anxiety. The search covered pharmacological studies, patents, and registered products that were focused on the promising Brazilian market. This report about Passiflora herbal medicinal products comprises eight sections: Passiflora genus (Passifloraceae); chemical constituents; mechanism of anxiolytic action; Passiflora extract: standardization and chemical marker; pharmacology, pharmacokinetics and safety; patents and intellectual property in Brazil; registered medicines containing Passiflora in Brazil; and patents and registered products containing Passiflora outside Brazil.

\section{Methods}

Empirical searches were conducted via the databases Scopus ${ }^{\circledR}$ (http://www.scopus.com) [11], Scirus (http://www. scirus.com) [12], SciFinder ${ }^{\circledR}$ (http://scifinder.cas.org/) [13], Google Scholar (https://scholar.google.com.br/) [14], as well as periodicals using the following three keywords: 'Passiflora incarnata', 'Passiflora edulis', and 'Passiflora alata'. Other keywords used with the genus Passiflora were extraction, pharmacophores, ADMET, flavonoids, and formulation. A search for clinical trials using the keywords 'anxiety' and 'Passiflora' were performed in the database ClinicalTrials. gov (https://clinicaltrials.gov), of the National Institutes of Health (NIH), an agency of the U.S. Department of Health and Human Services [15]. All of the information about the plants, their past and present therapeutic uses, and data about marketing of herbal medicines in Brazil and outside Brazil, including species of Passiflora in combination with other active ingredients, were taken directly from selected papers and searched in the following websites: the National Institute of Industrial Property (Instituto Nacional de Propriedade Industrial, INPI), https:/gru.inpi.gov.br/pePI/ servlet/PatenteServletController [16]; National Health Regulatory Agency (Agência Nacional de Vigilância Sanitária, ANVISA), https://consultas.anvisa.gov.br/ \#/medicamentos/, an agency of the Ministry of Health [17]; Trade-Related Aspects of Intellectual Property Rights (TRIPS Agreement) [18], the Brazilian Pharmacopoeia [19], Medicines and Healthcare Products Regulatory Agency (MHRA) of the United Kingdom [20], and European Medicines Agency [21]. 
The graphs and tables were constructed using Excel 2013.

2.1. Passiflora Genus (Passifloraceae). According Muschner and colleagues [22], the Passifloraceae family is divided into two tribes: Paropsieae, with six genera, is found throughout Europe, Africa, and Madagascar, and Passiflorieae, with 14 genera, is found in the Americas and in Europe. The genus Passiflora, belonging to the Passifloraceae family, contains approximately 530 species and 400 artificial hybrids [23] or, according to other authors, more than 600 species $[22,24,25]$. At least 140 are native to Brazil, and 70 of them produce edible fruits. Brazil is the largest producer of Passiflora fruits in the world, with a reported annual production of $923,035 t$ [26]. It is popularly known as passion fruit in English and "maracujazeiro" in Portuguese [27, 28]. Besides the nutritional use of the fruits, the passion flower is cultivated as an ornamental plant and used in the cosmetic and pharmaceutical industries. The sedative properties of its leaves and hypoglycemic activity of the flour produced from the epicarp of the fruit have already been described $[26,29]$. Species of Passiflora are rich in flavonoids, which have anxiolytic activity, among other activities. $P$. incarnata $\mathrm{L}$. is the most widely studied species, due to its chemical composition and its pharmacological effects [30]. However, biological activities similar to those described for $P$. incarnata have been reported for other Brazilian species of the same genus, providing an alternative source for the formulation of herbal medicines.

Despite the many different species of Passiflora, only two are reported in the Brazilian Pharmacopoeia, 6th Edition [19], Passiflora edulis Sims and Passiflora alata Curtis. In Brazil, herbal medicines are prepared using the native species $P$. alata, $P$. edulis f. flavicarpa [31], and the exotic $P$. incarnata. $P$. incarnata is the most widely studied from a pharmacological point of view and it is present in the official pharmaceutical codes of different countries, including the British Herbal Pharmacopoeia, the United States Homoeopathic Pharmacopoeia, the Homoeopathic Pharmacopoeia of India, the Pharmacopoeia Helvetica, the Egyptian, French, German and Swiss Pharmacopoeias, and the British Herbal Compendium [27, 31, 32].

There have been numerous taxonomical, pharmacological, and toxicological studies on P. edulis and P. alata, but for other species native to Brazil, although cataloged for a long time, there is still a lack of studies on their potential uses in food, cosmetics, and pharmaceuticals [32]. Different activities have been reported for P. incarnata, especially in the pharmaceutical field. These include its action on the central nervous system for the treatment of anxiety disorders and neuropsychic symptoms of menopause, such as pain, anxiety, sexual dysfunction, and sleep disorders.

2.2. Chemical Constituents. In phytochemical studies, some papers have reported that the flavonoids and alkaloids of Passiflora may be related to its anxiolytic properties [33-35]. Some variability of flavonoids may occur within this botanical genus throughout the year, and there are different methods to increase the concentration of these metabolites in the leaves [36]. The literature indicates that some species of Passiflora have differences in their flavonoid C-glycosides contents, and these differences are relevant to the characterization of their specific origins. For example, isovitexin is found in higher amounts in $P$. incarnata [33, 37], $P$. alata [38], and $P$. edulis var. flavicarpa and $P$. edulis var. edulis [38], although it was not detected in P. edulis var. edulis by Zucolotto and colleagues [39]. Moreover, orientin and vitexin are found in small amounts in the leaves of $P$. incarnata, $P$. alata, and P. edulis [37-40]. Furthermore, isoorientin is one of the major flavonoids in $P$. incarnata and $P$. edulis var. flavicarpa, but it is only detected in small concentrations in P. alata [37-39]. Additionally some C-glycosides were identified in just one species, such as luteolin-6C-chinovoside and luteolin-6-C-fucoside in P. edulis [24,33] and $2 "$-xylosylvitexin in P. alata [33]. A comparative metabolite profiling and fingerprinting of the genus Passiflora leaves were reported using a multiplex approach of UPLCMS and NMR analyzed by chemometric tools [41]. Thin layer chromatography can also be used in order to differentiate species [42]. Recently, new components were isolated and identified in the fruit peel of Passiflora edulis, including five flavonoids [43, 44].

Based on studies that indicate the presence of flavonoids in extracts of Passiflora and their pharmacological properties, a total flavonoid analysis has been proposed for the preliminary evaluation of this plant species [42, 45-49]. Furthermore, the C-glycosylated flavonoid may represent a particularly important chemical marker for the quality control of herbal medicines, enabling the identification of different species of Passiflora [46, 50, 51].

C-glycosylated flavonoids found in P. incarnata consist mainly of a glucose group directly linked to the aromatic nucleus only in positions 6 and 8 of the flavonoid core [52]. The aqueous extract is phytochemically characterized by a set of C-glycoside flavonoids such as vitexin (1), isovitexin (2), schaftoside (3), isoschaftoside (4), orientin (5), isoorientin (6), and swertisin (7) $[53,54]$. Moreover, the free flavonoids apigenin (8), luteolin (9), quercetin (10), kaempferol (11), and chrysin (12) are also found [33]. Figure 1 illustrates the chemical structures of the flavonoids of $P$. incarnata.

The alkaloids present in Passiflora are of the indole type ( $\beta$-carbolines), which are the second major known group of alkaloids [54]. Some of them have value in medicine as tranquilizers and for the treatment of hypertension [55]. P. incarnata is the most widely studied species containing alkaloids [24]. In studies carried out in the 1960s, harmine (13), harmol (14), harmaline (15), harmalol (16), and harman (17) were detected (Figure 2) [56]. Although the presence of traces of these alkaloids was confirmed [24], they were undetectable in most commercial materials [57]. Figure 2 shows the principal alkaloids mentioned above.

2.3. Mechanism of Anxiolytic Action. Events related to depression and anxiety, among others in the central nervous system, refer to the balance between chemical excitation and inhibition [58]. One of the mechanisms involves the 
<smiles>[Y]c1ccc(-c2oc3c([Y7])c([Y])c([Y])c(O)c3c(=O)c2[Y])cc1[R]</smiles>

\begin{tabular}{lcccccc}
\hline Flavonoids & R1 & R2 & R3 & R4 & R5 & R6 \\
\hline (1) Vitexin & $\mathrm{OH}$ & $\mathrm{H}$ & $\mathrm{H}$ & $\mathrm{H}$ & $\mathrm{OH}$ & Glucose \\
(2) Isovitexin & $\mathrm{OH}$ & $\mathrm{H}$ & $\mathrm{H}$ & Glucose & $\mathrm{OH}$ & $\mathrm{H}$ \\
(3) Schaftoside & $\mathrm{OH}$ & $\mathrm{H}$ & $\mathrm{H}$ & Glucose & $\mathrm{OH}$ & Arabinose \\
(4) Isoschaftoside & $\mathrm{OH}$ & $\mathrm{H}$ & $\mathrm{H}$ & Arabinose & $\mathrm{OH}$ & Glucose \\
(5) Orientin & $\mathrm{OH}$ & $\mathrm{OH}$ & $\mathrm{H}$ & $\mathrm{H}$ & $\mathrm{OH}$ & Glucose \\
(6) Isoorientin & $\mathrm{OH}$ & $\mathrm{OH}$ & $\mathrm{H}$ & Glucose & $\mathrm{OH}$ & $\mathrm{H}$ \\
(7) Swertisin & $\mathrm{OH}$ & $\mathrm{H}$ & $\mathrm{H}$ & Glucose & $\mathrm{OCH}_{3}$ & $\mathrm{H}$ \\
(8) Apigenin & $\mathrm{OH}$ & $\mathrm{H}$ & $\mathrm{H}$ & $\mathrm{H}$ & $\mathrm{OH}$ & $\mathrm{H}$ \\
(9) Luteolin & $\mathrm{OH}$ & $\mathrm{OH}$ & $\mathrm{H}$ & $\mathrm{H}$ & $\mathrm{OH}$ & $\mathrm{H}$ \\
(10) Quercetin & $\mathrm{OH}$ & $\mathrm{OH}$ & $\mathrm{OH}$ & $\mathrm{H}$ & $\mathrm{OH}$ & $\mathrm{H}$ \\
(11) Kaempferol & $\mathrm{H}$ & $\mathrm{OH}$ & $\mathrm{OH}$ & $\mathrm{H}$ & $\mathrm{OH}$ & $\mathrm{H}$ \\
(12) Chrysin & $\mathrm{H}$ & $\mathrm{H}$ & $\mathrm{H}$ & $\mathrm{H}$ & $\mathrm{OH}$ & $\mathrm{H}$ \\
\hline
\end{tabular}

FIgUre 1: Flavonoids of Passiflora incarnata.<smiles>[R]c1ccc2c(c1)[nH]c1c(C)nccc12</smiles>

(a)<smiles>[R]c1ccc2c3c([nH]c2c1)C(C)=NCC3</smiles>

(b)

\begin{tabular}{lccc}
\hline \multicolumn{3}{c}{ Alkaloids } \\
\hline A & $\mathrm{R}$ & $\mathrm{B}$ & $\mathrm{R}$ \\
\hline (13) Harmine & $\mathrm{OCH}_{3}$ & $(16)$ Harmaline & $\mathrm{OCH}_{3}$ \\
(14) Harmol & $\mathrm{OH}$ & $(17)$ Harmalol & $\mathrm{OH}$ \\
(15) Harman & $\mathrm{H}$ & & \\
\hline
\end{tabular}

Figure 2: Alkaloids of Passiflora incarnata.

$\gamma$-aminobutyric acid (GABA) system via binding to the benzodiazepine-site of the GABA type A receptor $\left(\mathrm{GABA}_{\mathrm{A}}\right)$, which can be modulated by allosteric agents, for example, benzodiazepines, which promote the regulation of the chloride flow through the ion channel complex [59]. The possibility of elaborating or identifying new drugs with chemical characteristics of benzodiazepines for the treatment of anxiety led to the formulation of pharmacophoric models, and the model designed by Cook is the reference in this field of study. The pharmacophoric model designed by Cook describes a lipophilic region, two hydrogen bond donor sites (HB1 and HB2), and a hydrogen bond acceptor site (A2) $[59,60]$. These characteristics are consistent with the chemical structure of flavonoids, mainly the two hydrogen bond-donating sites that are related to ether oxygen and a carbonyl group present in flavones, and the aromatic rings $\mathrm{A}$ and $\mathrm{B}$ corresponding to the lipophilic regions $\mathrm{L} 1$ and L2, respectively [61]. In order to elucidate some incongruencies related to actions not predicted by this model in the study of 6-methyl-3'-nitroflavone [62], a new pharmacophoric model was designed. In this new model, in addition to the regions described by Cook's model, there are two sites classified as S1 and S2 relative to electrostatic interaction of substituents in 6-position of flavone [61,63]. Additional studies revealed two new regions of steric repulsive around the $4^{\prime}$ - and $5^{\prime}$-regions of the B-ring $[61,64]$.

The chemical constituents responsible for the anxiolytic activity of Passiflora are not yet fully understood but the majority of published works suggest that phenolic substances, especially the flavonoid class, are related to this property [65-68]. The flavonoids identified in P. incarnata (Figure 1) probably act according to the pharmacophoric models described. The mechanism of action is probably related to the modulation of the $\gamma$-aminobutyric acid (GABA) system, because Passiflora flavonoids are partial agonists of $\mathrm{GABA}_{\mathrm{A}}$ receptors and inhibit the uptake of [3H]GABA into rat cortical synaptosomes [30, 67, 69, 70]. The review article written by Wasowski and Marder [58] 
describes flavonoids as $\mathrm{GABA}_{\mathrm{A}}$ receptor ligands, including apigenin and chrysin that bind to the benzodiazepinebinding site of the $\mathrm{GABA}_{\mathrm{A}}$ receptor, exhibiting anxiolytic activity, without evidencing sedation and muscle relaxant effects $[58,71]$. In vitro assays demonstrated that the flavonoid chrysin (5,7-dihydroxyflavone) has affinity for the benzodiazepine receptors and that it increases pentobarbital-induced hypnosis and reduces locomotor activity in mice after intraperitoneal administration of $30.0 \mathrm{mg} / \mathrm{kg}$ body weight (bw) [57]. This is reinforced by studies that indicate that the pre-administration of flumazenil, an antagonist of $\mathrm{GABA}_{\mathrm{A}}$ receptor, attenuates the anxiolytic effects of passionflower like diazepam. However, this is possible not the unique mechanism involved [30].

In one study, kaempferol exhibited a very low affinity for the benzodiazepine-binding site and was devoid of anxiolytic actions by the intraperitoneal route [58]. However, in another study to evaluate the anxiolytic activity of the flavonols, kaempferol, quercetin, and myricetin, in the elevated plus-maze after oral and intraperitoneal (i.p.) administration in mice, only kaempferol and quercetin were active after oral administration, although they were inactive via i.p. [72].

The harman alkaloids found in P. incarnata which belong to the $\beta$-carboline class have different structural characteristics that interact with benzodiazepine receptors. This class of alkaloids attracted the attention of Braestrup and colleagues [73] during studies with endogenous ligands for benzodiazepine receptors after the detection of $\beta$-carboline-3-carboxylic acid ethyl ester in normal human urine. This discovery was important because it was foreshadowing the synthesis of several derivatives of $\beta$-carboline compounds with important biological activity [74]. In addition, research involving $\beta$-carboline compounds has led to conceptual and experimental considerations, covering the role of ligands in the $\mathrm{GABA}_{\mathrm{A}}$ receptor modulation process in a spectrum that ranges from full agonists to full inverse agonists [75]. Furthermore, $\beta$-carboline alkaloids are consistent with the pharmacophoric model developed by Cook and coworkers [59, 60], enabling the recognition of a hydrogen bond acceptor (A2) site in the $\mathrm{NH}$ group, a hydrogen bond donor (H1) in $\mathrm{N}(2)$ [75], in addition to the positions in $\mathrm{C} 6$ and $\mathrm{C} 3$ framed in the lipid domain (LDi) [76].

\subsection{Passiflora Extract: Standardization and Chemical Marker.} The marketing of extracts obtained from plant drugs is advantageous for the industry in several ways, as it reduces the steps involved in the manufacturing of herbal medicine products, it minimizes waste production, and it simplifies analytical quality control. However, an important point for evaluation is the standardization of this extract obtained commercially. Standardization of raw plant materials can be done by the chemical quantification of substances or class of substances related to the therapeutic effects, or through the presence of chemical marker substances of the species. The most abundant substances in the leaves of this species belong to the class of flavonoids, especially C-glycosides, which are directly related to its pharmacological activities [24].
According to the current Brazilian regulations for herbal medicines with simplified registration, Normative Rule no. 02 determines that the main chemical marker of the $P$. incarnata extract is vitexin, which is considered to be the active ingredient of its aqueous extract. The range of a daily dosage varies from $30 \mathrm{mg}$ to $120 \mathrm{mg}$ of total flavonoids expressed as vitexin in an herbal medicine made from Passiflora [77]. According to the Assessment Report on P. incarnata, elaborated by the European Medicines Agency (EMA) that is affiliated to the European Union, the herbal extract prepared with hydroalcohol solution or acetone solution may contain at least $2.0 \%$ of flavonoids expressed as vitexin, and the daily dose recommended corresponds in most cases to about $20-30 \mathrm{mg}$ of total flavonoids [21]. The Brazilian Pharmacopoeia does not contain any information about the minimum flavonoid contents in extracts, but British and French Pharmacopoeias recommend at least $1.5 \%$ of flavonoids expressed as vitexin [78].

The continuous growing demand for plant derived therapeutic molecules obtained in a sustainable and ecofriendly manner favors biotechnological production leading to the production of plants with increased levels of desirable compounds with potential biological activity. Similarly, the development of innovative extraction techniques to obtain phytoconstituents that can be used in modern medicine is another approach that must be taken into account. On this point, accelerated solvent extraction can be used to obtain extracts enriched in polyphenolic compounds from different species of Passiflora sp. [38]. This extraction method offers many advantages such as good reproducibility and shorter extraction time, the possibility to adjust extraction temperature, and purification of extracts online. Fierascu and colleagues [79] suggest some techniques that may be combined and applied in the development of products based on Passiflora.

\subsection{Pharmacology, Pharmacokinetics, and Safety.} Information on the absorption, distribution, metabolism, elimination, and toxicity (ADMET) of a drug in the human body is of great importance for the characterization of a drug formulation regarding the treatment of a certain disease and its safety for the patient $[80,81]$. Knowledge of ADMET properties is usual for synthetic drugs; however, when the universe of substances present is expanded, such as in the case of products from plant species, there is a reduced level of information about these properties [80-82].

The reasons for this gap are the complexity of a formulation based on natural products, which generally includes a high number of substances in its composition that can suffer qualitative and quantitative variation of these constituents due to many factors, such as plant harvest and climatic factors [80, 81]. Currently, it is possible to apply standardized methods for the preparation of herbal medicines with the chemical composition controlled. However, the identification of the active substance is usually difficult, and this fact can compromise the knowledge of the ADMET properties in the body $[80,82]$. 
The alternative to deal with these peculiarities related to herbal medicines is the determination of ADMET properties of pure constituents of the formulation, through in vitro tests, for example, Caco-2 cells, human liver microsomes, and cultured human hepatocytes [80]. In this context, the ADMET properties of the flavonoids iso-orientin, isovitexin, luteolin, apigenin, and kaempferol present in $P$. incarnata have been described in the literature $[80,83,84]$.

Absorption processes are evaluated by blood-brain barrier $(\mathrm{BBB})$ penetration and human intestinal absorption (HIA) methods that demonstrated high absorption through human intestine and side effects on absorption through BBB for iso-orientin, isovitexin, and luteolin. Apigenin and kaempferol showed positive values for both BBB and HIA $[80,83,85]$. The importance of a substance crossing the $\mathrm{BBB}$ is partially related to the required biological activity, and this is based on structural and physicochemical characteristics, such as lipophilicity, molecular size, desolvation potential, pKa-to-charge ratio, and hydrogen bond [80, 86, 87].

In metabolic process, CYP450 is an isoenzyme that metabolizes several substances, including, carcinogens, fatty acids, bile acids, and steroids, which evidences its importance in the characterization of the metabolic properties of various substances. Among the previously mentioned flavonoids, only iso-orientin and isovitexin, have low CYP inhibitory promiscuity. However, all of them were nonsubstrate for all CYP450 substrates (2C9, 2D6), and most of them inhibited most of the CYP450 inhibitors (2C9 and 2D6) $[80,83,85]$. The inhibition of CYP450 isoforms is closely related to the metabolism of a substance and can lead to increased toxicity [85]. Aspects related to toxicity were measured based on biodegradability, Ames toxicity, and carcinogenicity. In general, the toxicological profile of the flavonoids indicates that they are not carcinogenic and, with the exception of iso-orientin and isovitexin, demonstrated to be negative for Ames toxicity [80, 83, 85].

Within a broader context, the flavonoids present in $P$. incarnata have a good ADMET profile and, considering an herbal formulation containing these substances, i.e., good absorption, metabolism, distribution, elimination, and low toxicity.

Given these premises, knowledge about pharmacokinetic parameters is an extremely important aspect for the development of any oral formulation of Passiflora extracts. The water solubility of flavone molecules, such as for most of the flavonoids, is limited, and it is $0.1 \mathrm{~g} / \mathrm{L}$ for chrysin. Flavonoid aglycones generally tend to have good membrane permeability, whereas flavonoid glycosides have poor membrane permeability, related to their ability to form hydrogen bonds, and consequently, aglycones are absorbed better and faster. Pure chrysin seems to be predominantly absorbed by passive diffusion. All flavones, including those with an unsubstituted B ring, are rapidly metabolized in the small intestine and then supplemented with biotransforms in the liver, while those that are not absorbed are affected by the additional metabolism of bacterial enzymes in the colon. The prolonged metabolism of the first pass of flavonoids, mainly by glucuronidation and sulfation, proved to be the main reason for their low bioavailability. Glucuronidation of flavones by UDP-glucuronosyltransferases (UGT) 1A1 represents together with sulfation by sulfotransferase (SULT) 1A3 and 1A1 the most important metabolic pathway of these natural molecules when ingested by humans. Chrysin is predominantly glucuronidated by UGT1A1, having preeminence over sulfation $[88,89]$.

General data of flavonoid excretion indicate that most of these glucuronides are subject to biliary excretion, with little urinary contribution. In the case of chrysin, only about $3 \%$ of the dose administered is excreted through the kidneys. However, most of the glucuronides tend to be pharmacologically inactive, although notable exceptions are known $[88,89]$.

The third volume of the World Health Organization monographs on selected medicinal plants contains the monograph of $P$. incarnata [57]. In this monograph, experimental pharmacology studies related to central nervous system depressant activity in mice are described. The aqueous or hydroalcohol extracts (30-40\% of ethanol) of the aerial parts reduces spontaneous motor activity, increased pentobarbital-induced sleeping time, and potentiated pentobarbital-induced sleeping time after intraperitoneal or intragastric administration. However, the aqueous extract seems to be more active than the hydroalcohol extract, since some activity is observed with the aqueous extract at $25.0 \mathrm{mg} / \mathrm{kg}$ (bw), while hydroalcohol extracts only have some activity at higher concentrations $(50.0 \mathrm{mg} / \mathrm{kg}$ or over) [57].

The aqueous extract is toxic to mice at $900.0 \mathrm{mg} / \mathrm{kg}$ bw i.p. and the oral median lethal dose $\left(\mathrm{LD}_{50}\right)$ of a $30 \%$ ethanol extract in mice was $37.0 \mathrm{ml} / \mathrm{kg}$ bw [57]. Other nonclinical information indicates that the acute and repeated dose toxicity is low, and the $\mathrm{LD}_{50}$ of the hydroalcoholic extract in mice and rats is higher than $15 \mathrm{~g} / \mathrm{kg}$ orally and higher than $3 \mathrm{~g} / \mathrm{kg}$ i.p. [21]. There is no evidence of genotoxicity, but $P$. incarnata is contraindicated during pregnancy because it seems to stimulate uterine contractions in animal models. It may cause drowsiness and therefore care is recommended for activities that require attention. Some adverse events that are very rare include hypersensitivity, ventricular tachycardia, nausea, vomiting, drowsiness and prolonged QT interval, thrombocytopenia, left ventricular failure, ventricular fibrillation, hepatic function abnormal, arrhythmia, tremor, agitation, and withdrawal syndrome. However, no correlation of serious adverse events and $P$. incarnata intake has been established. There are no reports regarding safety for nursing mothers and children, and the use of $P$. incarnata in these cases should be monitored by a physician $[21,57]$. Furthermore, the concomitant use of $P$. incarnata and sedatives such as benzodiazepines, zolpidem or barbiturates, alcohol, and clonidine is not recommended due to possible pharmacokinetic interactions [90].

Clinical research studies involving the use of Passiflora to treat anxiety were searched for in the ClinicalTrials.gov, a database maintained by the National Institutes of Health (NIH), which is an agency of the U.S. Department of Health and Human Services [15]. This database registers private and public clinical studies from throughout the world. There are six research studies registered that are listed in Table 1, all of 
TABLE 1: List of clinical trials related to the use of Passiflora to treat anxiety registered in NIH.

\begin{tabular}{|c|c|c|c|c|c|c|}
\hline Trial number & $\begin{array}{l}\text { Dosage } \\
\text { form }\end{array}$ & Formulation NAME & Stage & Period & $\begin{array}{c}\text { Reference } \\
\text { anxiolytic } \\
\text { AGENT }\end{array}$ & Status \\
\hline NCT00794456 & Tablet & $\begin{array}{l}\text { Pasalix: Passiflora incarnata L., Crataegus } \\
\text { oxyacantha L., Salix alba L. }\end{array}$ & Phase 3 & 6 weeks & $\begin{array}{l}\text { Valeriana } \\
\text { officinalis L. } \\
\quad(50 \mathrm{mg})\end{array}$ & $\begin{array}{l}\text { Completed } \\
\text { Oct } 2013\end{array}$ \\
\hline NCT01178632 & Tablet & $\begin{array}{l}\text { Passiflorine: Passiflora incarnata L., } \\
\text { Crataegus oxyacantha L., Salix alba L. }\end{array}$ & Phase 3 & 4 weeks & $\begin{array}{l}\text { Valeriana } \\
\text { officinalis L. }\end{array}$ & Unknown \\
\hline NCT00944268 & Liquid & $\begin{array}{c}\text { Passiflora incarnata L., Crataegus } \\
\text { oxyacantha L., Salix alba L. }\end{array}$ & Phase 3 & 30 days & None & Unknown \\
\hline NCT02065843 & Capsules & Passiflora incarnata L. $100 \mathrm{mg}$ & $\begin{array}{l}\text { Phase } 2 \\
\text { phase } 3\end{array}$ & $\begin{array}{l}1 \mathrm{~h} \text { before } \\
\text { dental } \\
\text { surgery }\end{array}$ & $\begin{array}{l}\text { Midazolam } \\
\quad(15 \mathrm{mg})\end{array}$ & $\begin{array}{l}\text { Completed } \\
\text { Sep } 2014\end{array}$ \\
\hline NCT03909906 & tablets & $\begin{array}{c}\text { Euphytose }^{\circledR} \text { : } 50 \mathrm{mg} \text { Valeriana officinalis L., } \\
40 \mathrm{mg} \text { Passiflora incarnata L., } 10 \mathrm{mg} \\
\text { Crataegus sp., } 10 \mathrm{mg} \text { Ballota nigra L. }\end{array}$ & $\begin{array}{l}\text { Not } \\
\text { applicable }\end{array}$ & 14 days & None & $\begin{array}{l}\text { Completed } \\
\text { Dec } 2019\end{array}$ \\
\hline NCT00997490 & $\begin{array}{l}\text { Film-coated } \\
\text { sugar-pill }\end{array}$ & $\begin{array}{c}\text { Neurapas balance: hypericum, valerian, } \\
\text { passionflower }\end{array}$ & Phase 3 & 6 weeks & None & $\begin{array}{l}\text { Completed } \\
\text { Feb } 2003\end{array}$ \\
\hline
\end{tabular}

Source: https://www.clinicaltrials.gov/. Accessed on May 19, 2020.

them with the species $P$. incarnata. Four studies have been concluded or terminated, and two are unknown. The results concerning the effectiveness or the reasons for discontinuation were not informed. Only one of the studies was conducted with monopreparations of Passiflora. The concomitant use of plant species in clinical trials makes it difficult to attribute any effect specifically to $P$ incarnata.

In the literature, there are few relevant clinical trials available for monopreparations of $P$. incarnata to support its use to treat anxiety, and the published studies should be considered preliminary and only suggestive of its effectiveness. The most complete study is described by Mori and colleagues [91], which was evaluated by The Cochrane Collaboration [92] and EMA [21]. According to these evaluations, the multicentre double-blind study performed in Japan over a 4-week period was adequately randomized, and the Jadad score was 5. In the study, 63 patients received $P$. incarnata extract (Passiflamin) and 71 patients received mexazolam. The initial doses were $90 \mathrm{mg}$ of Passiflamin or $1.5 \mathrm{mg}$ of mexazolam, which were further doubled. Although mexazolam was more effective, the efficacy of Passiflamin was significant to treat anxiety, tenseness, and irritation.

A small study with 36 patients with general anxiety over a 28-day period demonstrated that the use of passionflower extract (45 drops/day) is as effective as oxazepam $(30 \mathrm{mg} /$ day) [93]. The same research group evaluated the effect of $P$. incarnata extract (60 drops) associated with clonidine $(0.8 \mathrm{mg})$ in opiate addicts undergoing withdrawal [94]. In the study with 65 patients, the authors concluded that the daily administration of the combination over 14 days was better than only clonidine at $0.8 \mathrm{mg} /$ day.

Movafegh and colleagues [95] conducted a clinical study with 60 patients that were premedicated $90 \mathrm{~min}$ before a surgery. According to the numerical rating scale to assess anxiety and sedation, the anxiety scores of the group that received a $500 \mathrm{mg}$ tablet containing $1.01 \mathrm{mg}$ benzoflavone was lower than the anxiety scores of the group that received placebo, without inducing sedation. Another study involving preoperative anxiety was conducted with 60 patients 30 minutes before spinal anesthesia [96]. Patients received $5 \mathrm{~mL}$ of an aqueous solution containing $700 \mathrm{mg}$ of an aqueous extract of $P$. incarnata containing $2.8 \mathrm{mg}$ benzoflavone or $5 \mathrm{~mL}$ of mineral water. A small difference was observed between the two groups in the State Anxiety Inventory score, without sedation. Dantas and colleagues [97] studied the effect of $P$. incarnata (pill containing $260 \mathrm{mg}$ ) or midazolam (pill containing $15 \mathrm{mg}$ ) in forty volunteers for the control of anxiety before undergoing bilateral extraction of their mandibular third molar. Over $70 \%$ of the patients reported that they felt quiet or a little anxious with both treatments, and no significant differences were observed between the groups. However, $20 \%$ of the participants reported amnesia with midazolam. The authors found that $P$. incarnata showed an anxiolytic effect similar to midazolam.

The effect of $P$. incarnata on sleep quality was studied in a double-blind study with 41 volunteers [98]. Over a 7-day period, the volunteers received placebo (dried parsley infusion) or a $P$. incarnata infusion prepared with teabags containing $2 \mathrm{~g}$ of aerial parts and $250 \mathrm{~mL}$ of boiling water during $10 \mathrm{~min}$. The overnight polysomnography on the last night of the treatment indicated a significant increase of $5.2 \%$ of the sleep quality, but no significant effect on total sleep time and nocturnal awakenings.

It is important to highlight the lack of detail regarding the composition of $P$. incarnata extracts or even the composition of the formulations. Nonclinical studies suggest that aqueous extracts are more active than the $40 \%$ ethanol extracts, which indicates that small variations in chemical composition can be determinants in activity. The standardization of vegetable raw materials is of great importance in this area. The complex chemical composition of Passiflora extracts and the lack of knowledge of the pharmacological activity of each component increase the challenges, due to the difficulties in determining the most appropriate chemical marker in the standardization of the extract and in stability studies that any new studies should be directed to, for the 
development of formulations containing Passiflora. Other important considerations regarding the clinical trials presented here were previously mentioned by Miroddi and colleagues [30] who reviewed ethnopharmacological and clinical trials related to $P$. incarnata. The studies were performed with a small number of participants, and some studies had inadequate comparison between the placebo and the medications recommended for anxiety and gave little importance to the use of Passiflora found in some results. Thus, the clinical trials reported are pilot studies and are not enough to recognize the medicinal use of $P$. incarnata as being well-established. Moreover, the actual recommendations are still based on its long-standing use to relieve mild symptoms of mental stress. Thus, $P$. incarnata and other species of the genus offer a wide field for research that is still little explored, which should involve interdisciplinary and interinstitutional partnerships, covering the stages of phytochemical studies for standardization and developments in herbal medicines, along with nonclinical and clinical studies.

2.6. Patents and Intellectual Property in Brazil. The Agreement on Trade-Related Aspects of Intellectual Property Rights (TRIPS Agreement), of which Brazil is a signatory, established the current standards of intellectual property protection worldwide. It came into force on January 1, 1995 and is mandatory for all member countries of the World Trade Organization [18]. The TRIPS Agreement establishes minimum standards under international law related to patents, including standards for drugs. The members of the World Trade Organization (WTO) agreed on the development and implementation of patenting laws according to common patterns. These models state, among other things that patents should be granted for a minimum of twenty years, that patents may be granted for products and processes and that information for drug tests must be protected against "unfair commercial use".

In Brazil, the Law of Intellectual Property [99] excludes from patentability all plants and animals, or parts thereof, except for transgenic microorganisms with the requirements of patentability (novelty, inventive step, and industrial application) and those that do not constitute mere discoveries. Thus, Brazilian law does not allow the patenting of plant extracts. However, processes for obtaining extracts or isolated active ingredients from plants, pharmaceutical compositions and their methods of preparation, and other uses of the same products obtained from plants, are patentable. In this way, the growing herbal market aligned to government policies to promote regularization of medicinal plants and their derivatives [100], and the innovation for the development of herbal medicines justifies the product patent protection [101].

On that basis, the keyword $<$ Passiflora $>$ was selected as a search term, to search in the website of the National Institute of Industrial Property (Instituto Nacional de Propriedade Industrial, INPI). The results returned a miscellany of food products, cosmetics, packaging materials, manufacturing processes for simple syrups for dietary use, herbal syrups, and formulations containing bronchodilators, among others. The results of twenty-eight patents are shown in Table 2. Furthermore, there are recent patent files and they are concerned with obtaining new extracts, production processes, and analytical techniques.

\subsection{Registered Products Containing Passiflora in Brazil.} In Brazil, sanitary control of medicinal plants and herbal medicines is done through the "Agência Nacional de Vigilância Sanitária” (ANVISA-National Health Regulatory Agency), an agency of the Ministry of Health, which has the role of ensuring the health safety of products and services [102]. One of the actions taken by ANVISA to secure the health of the population is drug registration, whereby new drugs are evaluated for their safety, efficacy, and quality, before being marketed for use by the population.

The regulatory requirements for herbal medicines cover a range of aspects, from the supplier of the active ingredients through to the final product, produced under strict sanitary standards. The Collegiate Board of Directors Resolution (Resolução da Diretoria Colegiada, RDC) number 26 of May 13, 2014 provides for the registration and notification of traditional herbal products and herbal medicines to register with this agency [5]. The Normative Rule no 2 [77] published on the same date presents the lists of herbal medicines and traditional herbal products with simplified registration. Resolution RDC number 38 of June 18, 2014 [103] and resolution RDC 235 of June 20, 2018 [8] regulate adjustments, changes, extensions, updates, additions, and postregistration notifications of herbal medicines and traditional herbal products. Resolution RDC number 66 of November 26, 2014 establishes the information which has to be shown on the package leaflet of the traditional herbal product [104]. Resolution RDC number 105 of August 31, 2016 requires the presentation of the pesticide residue analysis reports or proof that the medicinal plants cultivated or collected in Brazil come from organic agriculture [105]. According to Resolution RDC 26/2014, both traditional herbal products and herbal medicines must be obtained exclusively from active raw material from plants and cannot include, in their composition, isolated or highly purified active substances [9].With technical and legal support in Brazil, it is possible to develop an innovative herbal medicine with simplified registration.

In Brazil, registration with the competent health regulatory agency is required in order to market herbal medicines. Table 3 shows the products and formulations registered on the Datavisa ANVISA website, including species of Passiflora in combination with other active ingredients. The search has included products registered since 1985 since ANVISA does not remove any product from the list in order to maintain the historical record, even after their expired registration. The list includes both regular and revalidated products and those for which registration was canceled or has expired. Although 86 products containing Passiflora are registered with ANVISA (Table 3), only 34 medicines are currently valid in Brazil (Figure 3).

The pharmaceutical forms widely marketed and used are capsules, tablets, fluid extract, and tincture, besides infusion, 
TABLe 2: List of patents in Brazil related to Passiflora.

\begin{tabular}{|c|c|c|}
\hline $\begin{array}{l}\text { Publication } \\
\text { number }\end{array}$ & Date & Title \\
\hline $\begin{array}{l}\text { BR } 102017027632 \\
5\end{array}$ & $\begin{array}{l}\text { Dec 20, } \\
2017\end{array}$ & Extract and flour of the peel fruit of Passiflora cincinnata Mast. (Passifloraceae) for use as hipolipment \\
\hline $\begin{array}{l}\text { BR } 102017020281 \\
0\end{array}$ & $\begin{array}{l}\text { Sep 22, } \\
2017\end{array}$ & $\begin{array}{l}\text { Preparation of functional goat yogurt with passion fruit (Passiflora edulis Sims) and mandacaru (Cereus } \\
\text { jamacaru DC.) jam }\end{array}$ \\
\hline $\begin{array}{l}\text { BR } 102017020087 \\
6\end{array}$ & $\begin{array}{l}\text { Sep 20, } \\
2017\end{array}$ & $\begin{array}{l}\text { Preparation and processing of extra jam with passion flower (Passiflora edulis Sims) and mandacaru } \\
\text { (Cereus jamacaru DC.) flavor }\end{array}$ \\
\hline $\begin{array}{l}\text { BR } 102017010267 \\
0\end{array}$ & $\begin{array}{l}\text { May 16, } \\
2017\end{array}$ & Food supplement based on fruits from Caatinga \\
\hline $\begin{array}{l}\text { BR } 102017001368 \\
5\end{array}$ & $\begin{array}{l}\text { Jan 23, } \\
2017\end{array}$ & $\begin{array}{c}\text { Antimicrobial potential of extracts from exotic fruit waste (tamarind (Tamarindus indica L.), grenadilla } \\
\text { (Passiflora ligularis Juss.), noni (Morinda citrifolia L.), dekopon (Citrus reticulata 'Blanco shiranui'), } \\
\text { sapoti (Manilkara zapota (L.) P. Royen), tamarillo (Solanum betaceum Cav.), and mirtilo (Vaccinium } \\
\text { myrtillus L.) }\end{array}$ \\
\hline $\begin{array}{l}\text { BR } 102016022442 \\
0\end{array}$ & $\begin{array}{l}\text { Nov } 28 \\
2016\end{array}$ & $\begin{array}{l}\text { Formulation and production of symbiotic fermented dairy produced with flaxseed (Linum usitatissimum } \\
\text { L.) and/or waste from the processing of yellow passion fruit (Passiflora edulis var. flavicarpa Deg.) }\end{array}$ \\
\hline $\begin{array}{l}\text { BR } 102016014976 \\
2\end{array}$ & $\begin{array}{l}\text { Jun } 24 \text {, } \\
2016\end{array}$ & $\begin{array}{c}\text { Sequential extraction process of bioactive compounds from passion fruit bagasse and the use of its } \\
\text { bioactive compounds }\end{array}$ \\
\hline $\begin{array}{l}\text { BR } 102015032464 \\
2\end{array}$ & $\begin{array}{l}\text { Dec } 15, \\
2015\end{array}$ & Formulation for topical use for photoprotection containing Passiflora cincinnata Mast. \\
\hline $\begin{array}{l}\text { BR } 112017015446 \\
3\end{array}$ & $\begin{array}{l}\text { Dec } 10 \\
2015\end{array}$ & Homoeopathic method for treating colic, intestinal gases, and malaise in children \\
\hline $\begin{array}{l}\text { BR } 102015006517 \\
5\end{array}$ & $\begin{array}{c}\text { Mar 24, } \\
2015\end{array}$ & $\begin{array}{l}\text { Mixed flour; sweet cookie; and process for producing mixed flour and sweet cookies containing plant } \\
\text { extracts of Brazil nuts (Bertholletia excelsa Bonpl.), manioc (Manihot esculenta Crantz), peach palm } \\
\text { (Bactris gasipaes Kunth), and passion fruit (Passiflora edulis Sims) }\end{array}$ \\
\hline $\begin{array}{l}\text { BR } 102015002902 \\
0\end{array}$ & $\begin{array}{l}\text { Fev 10, } \\
2015\end{array}$ & Lotion based on Ganoderma lucidum (Curtis) P. Karst. Spores \\
\hline $\begin{array}{l}\text { BR } 102015001385 \\
0\end{array}$ & $\begin{array}{l}\text { Jan } 22 \text {, } \\
2015\end{array}$ & Composition of products without added sugar based on yellow passion fruit flour \\
\hline $\begin{array}{l}\text { BR } 102015002897 \\
0\end{array}$ & $\begin{array}{c}\text { Jan } 16, \\
2015\end{array}$ & Production of antibiotic containing Passiflora edulis Sims extract and its use \\
\hline $\begin{array}{l}\text { BR } 112016006227 \\
2\end{array}$ & $\begin{array}{l}\text { Sep 25, } \\
2014\end{array}$ & Lipid extract of passion fruit seeds \\
\hline $\begin{array}{l}\text { BR } 112015014492 \\
6\end{array}$ & $\begin{array}{c}\text { Dec 20, } \\
2013\end{array}$ & Composition of plant extract for treatment of opious and alcohol abuse \\
\hline $\begin{array}{l}\text { BR } 112015014351 \\
2\end{array}$ & $\begin{array}{c}\text { Dec } 18, \\
2013\end{array}$ & $\begin{array}{c}\text { Extract of Passiflora seeds and cosmetic, dermatological, and nutraceutical compositions comprising the } \\
\text { same }\end{array}$ \\
\hline $\begin{array}{l}\text { BR } 102012026263 \\
0\end{array}$ & $\begin{array}{l}\text { Oct } 08 \text {, } \\
2012\end{array}$ & Composition for hair mask without gluten \\
\hline $\begin{array}{l}\text { BR } 102012026281 \\
9\end{array}$ & $\begin{array}{l}\text { Oct } 08 \text {, } \\
2012\end{array}$ & Composition for hair conditioner without gluten \\
\hline $\begin{array}{l}\text { BR } 102012021728 \\
7\end{array}$ & $\begin{array}{c}\text { Aug 29, } \\
2012\end{array}$ & Nanoparticle \\
\hline $\begin{array}{l}\text { BR } 102012022381 \\
3\end{array}$ & $\begin{array}{c}\text { Aug 28, } \\
2012\end{array}$ & Compositions for hair oil \\
\hline $\begin{array}{l}\text { BR } 102012019583 \\
6\end{array}$ & Jul 09, 2012 & Compositions for hair mask \\
\hline PI $0816292-1$ & $\begin{array}{l}\text { Sep 03, } \\
2008\end{array}$ & $\begin{array}{c}\text { Process for the preparation of an extract of Passiflora alata Curtis plant and its use in co } \\
\text { pharmaceutical compositions }\end{array}$ \\
\hline PI 0800544-3 & $\begin{array}{l}\text { Feb 01, } \\
2008\end{array}$ & $\begin{array}{l}\text { Analytical technology based on pyrolysis coupled to gas chromatography/mass spectrometry for the } \\
\text { characterization and obtaining chemical compounds from extracts of Passiflora alata Curtis dried by } \\
\text { nebulization }\end{array}$ \\
\hline PI $0800705-5$ & $\begin{array}{l}\text { Jan } 15 \\
2008\end{array}$ & Flavor capsules for decreasing absorption of lipids and carbohydrates \\
\hline PI 0602106-9 & $\begin{array}{l}\text { May 25, } \\
2006\end{array}$ & $\begin{array}{l}\text { Process for preparing a product based on Passiflora incarnata L., pharmaceutical product, and } \\
\text { pharmaceutical composition, use, and method of treatment of anxiety and insomnia }\end{array}$ \\
\hline PI $0501200-7$ & $\begin{array}{l}\text { Feb 16, } \\
2005\end{array}$ & Process for obtaining energy drink based on coconut water and natural passion fruit juice and honey \\
\hline PI 0501199-0 & $\begin{array}{l}\text { Feb 16, } \\
2005\end{array}$ & Process for obtaining energy drink based on coconut water and natural passion fruit juice \\
\hline PI 0203346-1 & $\begin{array}{l}\text { Jun } 26 \text {, } \\
2002\end{array}$ & $\begin{array}{c}\text { Composition of synergistic effect with plant active ingredients for higher activities of hydration and } \\
\text { tissue regeneration, dermal protection against aggressive external agents, as lotion, cream, gel, or } \\
\text { cellulose scarves, presented ready use }\end{array}$ \\
\hline
\end{tabular}


TABle 3: List of ANVISA registered products containing Passiflora sp.

\begin{tabular}{|c|c|c|c|c|}
\hline Product/category & Dosage form & Manufacturer Code & Status & Active \\
\hline $\begin{array}{l}\text { A SAÚDE DA MULHER/ } \\
\text { antispasmodic, anticholinergic, } \\
\text { drug combination }\end{array}$ & Oral solution & $57.507 .378 / 0003-65$ & Valid & $\begin{array}{c}\text { Sodium salicilate/Passiflora alata Curtis } \\
\text { (fluid extract)/'Agoniada pluméria' } \\
\text { (tincture)/bitter orange peel (fluid } \\
\text { extract) }\end{array}$ \\
\hline $\begin{array}{l}\text { A SAÚDE DA MULHER/ } \\
\text { antispasmodic, anticholinergic, } \\
\text { drug combination }\end{array}$ & $\begin{array}{l}\text { Simple dragee/oral } \\
\text { solution }\end{array}$ & $45.992 .062 / 0001-65$ & Canceled & $\begin{array}{l}\text { Sodium salicilate/Passiflora dry extract/ } \\
\text { 'Agoniada' dry extract }\end{array}$ \\
\hline ACALMIL/herbal compound & Coated tablet & $29.333 .218 / 0001-40$ & Canceled & $\begin{array}{c}\text { Passiflora incarnata L./Salix alba L. } \\
\text { (leaves extract)/Crataegus oxyacantha } \mathrm{L} . \\
\text { extract }\end{array}$ \\
\hline ACALMIL/herbal compound & Coated tablet & $92.265 .552 / 0001-40$ & Canceled & $\begin{array}{c}\text { Passiflora incarnata L./Salix alba L. } \\
\text { (leaves extract)/Crataegus oxyacantha } \mathrm{L} \text {. } \\
\text { extract }\end{array}$ \\
\hline $\begin{array}{l}\text { ALPHALIV/simple Herbal, } \\
\text { simple anxiolytic }\end{array}$ & Oral solution/coated tablet & 09.545.589/0001-88 & Valid & Passiflora incarnata $L$. \\
\hline $\begin{array}{l}\text { ANSIODORON/potentized } \\
\text { preparation }\end{array}$ & Tablet & $56.992 .217 / 0001-80$ & Valid & $\begin{array}{c}\text { Avena sativa L./Passiflora alata Curtis/ } \\
\text { Valeriana officinalis L } \\
\text { Caesalpinia ferrea Mart. /Roripa }\end{array}$ \\
\hline $\begin{array}{l}\text { BRONQUIOGEN/herbal } \\
\text { compound }\end{array}$ & Oral solution & $51.603 .488 / 0001-82$ & Canceled & $\begin{array}{l}\text { nasturtium Beck/Mikania glomerata } \\
\text { Spreng./ Lantana camara L./Passiflora } \\
\text { alata Curtis/Melissa officinalis L./ } \\
\text { Myrospermum erythroxylum Allem }\end{array}$ \\
\hline CALMAN/herbal compound & Coated tablet/oral solution & $02.433 .631 / 0001-20$ & Valid & $\begin{array}{c}\text { Crataegus rhipidophylla Gand./Passiflora } \\
\text { incarnata L./Salix alba L. }\end{array}$ \\
\hline CALMAN/herbal compound & Coated tablet/oral solution & 64.088.172/0001-41 & Canceled & $\begin{array}{c}\text { Crataegus rhipidophylla Gand./Salix alba } \\
\text { L./Passiflora incarnata L. }\end{array}$ \\
\hline $\begin{array}{l}\text { CALMANTE FARMAERVAS/ } \\
\text { herbal compound }\end{array}$ & Oral solution & $60.565 .520 / 0001-73$ & Canceled & $\begin{array}{c}\text { Melissa officinalis L./Passiflora alata } \\
\text { Curtis /Valeriana officinalis L./Lavandula } \\
\text { officnalis Chaix }\end{array}$ \\
\hline $\begin{array}{l}\text { CALMAPAX/similar, associated } \\
\text { natural products }\end{array}$ & $\begin{array}{l}\text { Coated tablet/oral } \\
\text { solution /cropped }\end{array}$ & $33.173 .097 / 0002-74$ & Canceled & $\begin{array}{c}\text { Passiflora incarnata L./Erythrina } \\
\text { mulungu Mart./Matricaria chamomilla } \\
\text { L./ Melissa officinalis L. (only in oral } \\
\text { solution) }\end{array}$ \\
\hline $\begin{array}{l}\text { CALMASYN/simple herbal, } \\
\text { simple analytic }\end{array}$ & Oral solution/coated tablet & $17.562 .075 / 0001-69$ & Valid & Passiflora incarnata $L$ \\
\hline CALMAVITA/simple herbal & Hard gelatin capsule & $56.646 .953 / 0001-86$ & Canceled & $\begin{array}{l}\text { Passiflora incarnata } L . \\
\text {. }\end{array}$ \\
\hline CALMI/herbal compound & Oral solution & 17.299.140/0001-05 & Canceled & $\begin{array}{c}\text { aurantium L./Cymbopogon citratus Stapf/ } \\
\text { Passiflora alata Curtis }\end{array}$ \\
\hline ACALMIL/herbal compound & Syrup & $06.597 .801 / 0001-62$ & Valid & Passiflora incarnata $L$ \\
\hline $\begin{array}{l}\text { CALMIPLAN/herbal } \\
\text { compound }\end{array}$ & Coated tablet & $47.100 .862 / 0001-50$ & Canceled & $\begin{array}{l}\text { Passiflora incarnata L./Salix alba L./ } \\
\text { Crataegus rhipidophylla Gand. }\end{array}$ \\
\hline $\begin{array}{l}\text { CALMOPLANTAS/simple } \\
\text { herbal, simple anxiolytic }\end{array}$ & $\begin{array}{l}\text { Tincture/hard gelatin } \\
\text { capsule }\end{array}$ & $79.634 .572 / 0001-82$ & Valid & $\begin{array}{l}\text { Passiflora incarnata L./Salix alba L./ } \\
\text { Crataegus rhipidophylla Gand. }\end{array}$ \\
\hline $\begin{array}{l}\text { CALMOXIL/simple herbal, } \\
\text { simple anxiolytic }\end{array}$ & Coated tablet/oral solution & $28.643 .633 / 0001-37$ & Canceled & Passiflora incarnata $L$. \\
\hline $\begin{array}{l}\text { CARDIOPAX GOTAS/ } \\
\text { Homeopathic association }\end{array}$ & Oral solution & $76.440 .528 / 0001-43$ & Canceled & $\begin{array}{l}\text { Passiflora incarnata L./Crataegus } \\
\text { rhipidophylla Gand./Digitalis sp. }\end{array}$ \\
\hline $\begin{array}{l}\text { CARDIOSETYL M/simple } \\
\text { herbal, simple anxiolytic }\end{array}$ & Oral solution & 21.573.449.0001-19 & Canceled & Passiflora incarnata $L$ \\
\hline $\begin{array}{l}\text { CARDIOSETYL M/herbal } \\
\text { compound/antispasmodic }\end{array}$ & Oral solution & $21.573 .449 / 0001-19$ & Canceled & $\begin{array}{l}\text { Passiflora alata Curtis/Crataegus } \\
\text { rhipidophylla Gand./Erythrina mulungu } \\
\text { Mart./ Leptolobio elegans Vog }\end{array}$ \\
\hline DALAY/simple herbal & Coated tablet/oral solution & 01.858.973/0001-29 & Valid & Passiflora dry extract \\
\hline DYRAJAIA/herbal compound & Tincture & 02.007.074/0001-85 & Canceled & $\begin{array}{c}\text { Passiflora alata Curtis/Dorstenia } \\
\text { multiformis Miq. }\end{array}$ \\
\hline $\begin{array}{l}\text { ELIXIR DE MARACUJÁ } \\
\text { COMPOSTO FARMAERVAS/ } \\
\text { herbal compound }\end{array}$ & Elixir & $60.565 .520 / 0001-73$ & Canceled & $\begin{array}{c}\text { Passiflora alata Curtis /Paullinia cupana } \\
\text { Kunth/ Valeriana officinalis L. }\end{array}$ \\
\hline
\end{tabular}


TABle 3: Continued.

\begin{tabular}{|c|c|c|c|c|}
\hline Product/category & Dosage form & Manufacturer Code & Status & Active \\
\hline $\begin{array}{l}\text { EQUILIBRISSE/simple herbal, } \\
\text { simple anxiolytic }\end{array}$ & Coated tablet & 05.161.069/0001-10 & Valid & Passiflora dry extract \\
\hline $\begin{array}{l}\text { EQUILIBRISSE/simple herbal, } \\
\text { simple anxiolytic }\end{array}$ & Coated tablet & 05.161.069/0001-10 & Valid & Passiflora incarnata $L$. \\
\hline $\begin{array}{l}\text { ELIXIR DE CEREUS } \\
\text { COMPOSTO/herbal compound }\end{array}$ & Oral solution & $92.695 .816 / 0001-03$ & Canceled & $\begin{array}{c}\text { Crataegus tincture/Cereus grandiflorus } \\
\text { (L.) Mill./Valeriana officinalis L./ } \\
\text { Passiflora alata Curtis }\end{array}$ \\
\hline $\begin{array}{l}\text { ERVA SILVINA COMPOSTA/ } \\
\text { herbal compound }\end{array}$ & Elixir & 92.943.992/0001-09 & Canceled & $\begin{array}{l}\text { Casearia sylvestris Sw./Aristolochia } \\
\text { cymbifera Martius/Passiflora alata Curtis }\end{array}$ \\
\hline $\begin{array}{l}\text { FIMATOSAN/Associated } \\
\text { natural products }\end{array}$ & Oral solution & $33.379 .887 / 0001-96$ & Canceled & $\begin{array}{c}\text { Caesalpinia ferrea Mart./Roripa } \\
\text { nasturtium Beck/Mikania glomerata } \\
\text { Spreng./Passiflora alata Curtis/ } \\
\text { Polypodium vulgare/Myrospermum } \\
\text { erythroxylum Allem./Lantana camara } \\
\text { Linné }\end{array}$ \\
\hline $\begin{array}{l}\text { FIQUEZEN/simple herbal, } \\
\text { simple anxiolytic }\end{array}$ & Coated tablet/oral solution & $17.875 .154 / 0001-20$ & Valid & Passiflora dry extract \\
\hline $\begin{array}{l}\text { FITOCALM/simple herbal, } \\
\text { simple anxiolytic }\end{array}$ & Coated tablet & $84.684 .620 / 0001-87$ & Valid & Passiflora incarnata L. \\
\hline FITOCALMIN/simple herbal & Hard gelatin capsule & $14.186 .324 / 0001-70$ & Canceled & Passiflora incarnata $L$ \\
\hline $\begin{array}{l}\text { FLORINY/Anxiolytics-drug } \\
\text { combination/herbal compound }\end{array}$ & Coated tablet/oral solution & $64.088 .172 / 0001-41$ & Canceled & $\begin{array}{c}\text { Passiflora incarnata L./Salix alba L./ } \\
\text { Crataegus oxyacantha L. }\end{array}$ \\
\hline $\begin{array}{l}\text { MARACUGINA COMPOSTA/ } \\
\text { herbal compound/anxiolytic }\end{array}$ & Oral solution/coated tablet & $61.082 .426 / 0002-07$ & Canceled & $\begin{array}{c}\text { Erythrina mulungu Mart./Crataegus } \\
\text { rhipidophylla Gand./Passiflora alata } \\
\text { Curtis }\end{array}$ \\
\hline $\begin{array}{l}\text { MARACUGINA COMPOSTA/ } \\
\text { herbal compound }\end{array}$ & Oral solution/coated tablet & $67.866 .665 / 0002-34$ & Canceled & $\begin{array}{l}\text { Passiflora alata Curtis/Erythrina mulungu } \\
\text { Mart./Crataegus rhipidophylla Gand. }\end{array}$ \\
\hline $\begin{array}{l}\text { MARACUGINA COMPOSTA/ } \\
\text { herbal compound }\end{array}$ & Oral solution/coated tablet & 02.932.074/0001-91 & Canceled & $\begin{array}{l}\text { Passiflora alata Curtis/Erythrina mulungu } \\
\text { Mart./Crataegus rhipidophylla Gand. }\end{array}$ \\
\hline $\begin{array}{l}\text { MARACUGINA PI/ simple } \\
\text { herbal, simple anxiolytic }\end{array}$ & Coated tablet & $61.082 .426 / 0002-07$ & Valid & Passiflora dry extract \\
\hline $\begin{array}{l}\text { MARACUGINA PI/ simple } \\
\text { herbal, simple anxiolytic }\end{array}$ & Coated tablet & $61.082 .426 / 0002-07$ & Valid & Passiflora incarnata $L$. \\
\hline $\begin{array}{l}\text { MARACUJÁ CONCENTRIX/ } \\
\text { herbal compound, simple } \\
\text { anxiolytic }\end{array}$ & $\begin{array}{l}\text { Simple dragees/oral } \\
\text { solution }\end{array}$ & 05.044.984/0001-26 & Canceled & $\begin{array}{c}\text { Crataegus rhipidophylla Gand./Passiflora } \\
\text { incarnata L./Salix alba L. }\end{array}$ \\
\hline $\begin{array}{l}\text { MARACUJÁ GOTAS/simple } \\
\text { herbal }\end{array}$ & Hydroalcoholic solution & $78.950 .011 / 0001-20$ & Canceled & Passiflora incarnata $L$. \\
\hline $\begin{array}{l}\text { MARACUJÁ HERBARIUM/ } \\
\text { simple herbal, simple anxiolytic }\end{array}$ & $\begin{array}{l}\text { Hard gelatin capsule/ } \\
\text { coated tablet }\end{array}$ & $78.950 .011 / 0001-20$ & Valid & Passiflora incarnata $L$. \\
\hline $\begin{array}{l}\text { MULUNGU BROMETADO/ } \\
\text { similar }\end{array}$ & Syrup & $10.419 .935 / 0001-60$ & Canceled & $\begin{array}{c}\mathrm{KBr} / \mathrm{NaBr} / \mathrm{NH} 4 \mathrm{Br} / \text { Atropa belladonna } \\
\text { tincture/Hyosciamus niger L. Tincture/ } \\
\text { Passiflora alata Curtis }\end{array}$ \\
\hline $\begin{array}{l}\text { NERVITON/Associated } \\
\text { phytotherapics }\end{array}$ & Elixir & $92.751 .965 / 0001-34$ & Canceled & $\begin{array}{c}\text { Passiflora alata Curtis/Ptychopetalum } \\
\text { olacides Benth/Cola nitida Schott \& Endl./ } \\
\text { Paullinia cupana Kunth/thiamine } \\
\text { hydrochloride }\end{array}$ \\
\hline $\begin{array}{l}\text { NEUREXAN/Dynamized } \\
\text { compound }\end{array}$ & Sublingual tablet & 05.994.539/0001-27 & Valid & $\begin{array}{c}\text { Avena sativa L./ Coffea arabica L./ } \\
\text { Passiflora incarnata L./Zincum } \\
\text { isovalerianicum }\end{array}$ \\
\hline NUIT/herbal compound & Coated tablet & 49.475.833/0001-06 & Canceled & $\begin{array}{c}\text { Passiflora incarnata L./ Valeriana } \\
\text { officinalis L./Crataegus rhipidophylla } \\
\text { Gand. }\end{array}$ \\
\hline PASALIX/herbal compound & Coated tablet & $60.726 .692 / 0001-81$ & Valid & $\begin{array}{c}\text { Crataegus rhipidophylla Gand./Passiflora } \\
\text { incarnata L./Salix alba L. }\end{array}$ \\
\hline $\begin{array}{l}\text { PASALIX PI/simple herbal, } \\
\text { simple anxiolytic }\end{array}$ & Coated tablet/oral solution & $60.726 .692 / 0001-81$ & Valid & Passiflora incarnata L. \\
\hline PASIC/herbal compound & Coated tablet/oral aerosol & $44.734 .671 / 0001-51$ & Canceled & $\begin{array}{l}\text { Passiflora incarnata L./ Crataegus } \\
\text { rhipidophylla Gand./Salix alba L. }\end{array}$ \\
\hline
\end{tabular}


TABle 3: Continued.

\begin{tabular}{|c|c|c|c|c|}
\hline Product/category & Dosage form & Manufacturer Code & Status & Active \\
\hline $\begin{array}{l}\text { PASSANEURO/herbal } \\
\text { compound }\end{array}$ & Coated tablet & $47.100 .862 / 0001-50$ & Canceled & $\begin{array}{l}\text { Passiflora dry extract/ Erithrina mulungu } \\
\text { Mart./Matricaria chamomilla L. }\end{array}$ \\
\hline PASSICALM/herbal compound & Oral solution & $85.776 .524 / 0001-21$ & Canceled & $\begin{array}{c}\text { Erithrina mulungu Mart./Valeriana } \\
\text { officinalis L./ Passiflora alata Curt }\end{array}$ \\
\hline PASSIENE/simple herbal & Syrup & $78.950 .011 / 0001-20$ & Canceled & Passiflora dry extract \\
\hline PASSIENE/simple herbal & Syrup/ coated tablet & $78.950 .011 / 0001-20$ & Valid & Passiflora incarnata $L$ \\
\hline $\begin{array}{l}\text { PASSIFLORA/herbal } \\
\text { compound }\end{array}$ & Tincture & 02.007.074/0001-85 & Canceled & $\begin{array}{c}\text { Passiflora dry extract/ Erithrina mulungu } \\
\text { Mart. }\end{array}$ \\
\hline $\begin{array}{l}\text { PASSIFLORA ALTHAIA/ } \\
\text { simple herbal, simple anxiolytic }\end{array}$ & Oral solution & $48.344 .725 / 0007-19$ & Valid & Passiflora incarnata $L$. \\
\hline $\begin{array}{l}\text { PASSIFLORA CATARINENSE/ } \\
\text { simple herbal, simple anxiolytic }\end{array}$ & Coated tablet & $84.684 .620 / 0001-87$ & Valid & Passiflora incarnata $L$. \\
\hline $\begin{array}{l}\text { PASSIFLORA COMPOSTA/ } \\
\text { herbal compound }\end{array}$ & $\begin{array}{c}\text { Oral solution/ simple } \\
\text { dragee }\end{array}$ & $42.341 .149 / 0001-84$ & Canceled & $\begin{array}{l}\text { Crataegus rhipidophylla Gand./Passiflora } \\
\text { incarnata L./Eerythrina mulungu Mart. }\end{array}$ \\
\hline $\begin{array}{l}\text { PASSIFLORA COMPOSTA/ } \\
\text { herbal compound }\end{array}$ & Elixir & $61.299 .111 / 0001-35$ & Canceled & $\begin{array}{l}\text { Erythrina mulungu Mart./Melissa } \\
\text { officinalis L./Passiflora alata Curtis }\end{array}$ \\
\hline $\begin{array}{l}\text { PASSIFLORA DA ÍNDIA/ } \\
\text { associated natural products }\end{array}$ & Elixir & $87.104 .170 / 0001-02$ & Canceled & $\begin{array}{c}\text { Passiflora alata Curtis/ Atropa belladonna } \\
\text { L./ Erythrina mulungu Mart./Citrus } \\
\text { limetta Risso/Cereus grandiflorus (L.) } \\
\text { Mill. }\end{array}$ \\
\hline $\begin{array}{l}\text { PASSIFLORA KLEIN/simple } \\
\text { herbal, simple anxiolytic }\end{array}$ & Tincture & $92.762 .277 / 0001-70$ & Valid & Passiflora incarnata $L$. \\
\hline $\begin{array}{l}\text { PASSIFLORA ORIENT/simple } \\
\text { herbal }\end{array}$ & Hard gelatin capsule & 73.657.876/0001-89 & Canceled & Passiflora incarnata $L$. \\
\hline $\begin{array}{l}\text { PASSIFLORINE/herbal } \\
\text { compound }\end{array}$ & $\begin{array}{l}\text { Oral solution/simple } \\
\text { dragee }\end{array}$ & $33.388 .182 / 0001-79$ & Canceled & $\begin{array}{l}\text { Passiflora incarnata L./Salix alba L./ } \\
\text { Crataegus rhipidophyla Gand./Calcium } \\
\text { gluconate/Cholecalciferol/low molecular } \\
\text { weight peptides/magnesium hyposulfium }\end{array}$ \\
\hline $\begin{array}{l}\text { PASSIFLORINE PI/simple } \\
\text { herbal, simple anxiolytic }\end{array}$ & Coated tablet & $23.668 .196 / 0001-92$ & Valid & Passiflora dry extract \\
\hline PASSIPAX/simple herbal & Oral solution & $04.656 .253 / 001-79$ & Valid & Passiflora incarnata L. \\
\hline $\begin{array}{l}\text { PAZINE/simple herbal, simple } \\
\text { anxiolytic }\end{array}$ & Coated tablet & $64.088 .172 / 0001-41$ & Canceled & Passiflora incarnata $L$. \\
\hline $\begin{array}{l}\text { PAZINE/simple herbal, simple } \\
\text { anxiolytic }\end{array}$ & Coated tablet & 07.670.111/0001-54 & Valid & Passiflora incarnata $L$. \\
\hline $\begin{array}{l}\text { PHYTOCALM / herbal } \\
\text { compound }\end{array}$ & Syrup/hard gelatin capsule & $84.684 .620 / 0001-87$ & Canceled & $\begin{array}{c}\text { Passiflora incarnata L./Valeriana } \\
\text { officinalis L./Matricaria chamomilla L./ } \\
\text { Crataegus oxyacantha L./Erythrina } \\
\text { mulungu Mart. }\end{array}$ \\
\hline $\begin{array}{l}\text { PRAKALMAR/Simple herbal, } \\
\text { simple anxiolytic }\end{array}$ & Coated tablet & $02.433 .631 / 0001-20$ & Valid & Passiflora incarnata $L$. \\
\hline $\begin{array}{l}\text { PRASILENCE/Simple herbal, } \\
\text { simple anxyolitic }\end{array}$ & Oral solution/coated tablet & $25.773 .037 / 0001-83$ & Valid & Passiflora incarnata $L$. \\
\hline $\begin{array}{l}\text { RITMONEURAN/Herbal } \\
\text { compound }\end{array}$ & $\begin{array}{l}\text { Hard gelatin capsule/oral } \\
\text { solution }\end{array}$ & $92.695 .691 / 0001-03$ & Canceled & $\begin{array}{c}\text { Passiflora alata Curtis/Erythrina mulungu } \\
\text { Mart./Leptolobio elegans Vog/Adonis } \\
\text { vernalis L. }\end{array}$ \\
\hline $\begin{array}{l}\text { RITMONEURAN RTM/simple } \\
\text { anxiolytic, simple herbal }\end{array}$ & $\begin{array}{l}\text { Hard gelatin capsule/oral } \\
\text { solution/ coated tablet }\end{array}$ & $92.695 .691 / 0001-03$ & Valid & Passiflora dry extract \\
\hline $\begin{array}{l}\text { SALSAPARILHA } \\
\text { COMPOSTO/Associated } \\
\text { natural products }\end{array}$ & Elixir & 92.943.992/0001-09 & Canceled & $\begin{array}{c}\text { Smilax japicanga Griseb./Baccharis } \\
\text { genistelloides Persoon/Plantago major L./ } \\
\text { Aristolochia cymbifera Martius/Passiflora } \\
\text { incarnata L. }\end{array}$ \\
\hline SEAKALM/herbal compound & Coated tablet & $02.456 .955 / 0001-83$ & Canceled & $\begin{array}{l}\text { Passiflora incarnata L./Salix alba L./ } \\
\text { Crataegus rhipidophylla Gand. }\end{array}$ \\
\hline $\begin{array}{l}\text { SEAKALM/simple anxiolytic, } \\
\text { simple herbal }\end{array}$ & Coated tablet/oral solution & $02.456 .955 / 0001-83$ & Valid & Passiflora incarnata $L$. \\
\hline SEDACAL/ simple herbal & Hard gelatina capsule & 01.845.448/0001-79 & Canceled & Passiflora incarnata $L$ \\
\hline $\begin{array}{l}\text { SEDANUS/associated natural } \\
\text { products }\end{array}$ & Oral solution & $67.866 .665 / 0002-34$ & Canceled & $\begin{array}{l}\text { Crataegus oxyacantha L./Passiflora } \\
\text { incarnata L./Erythrina mulungu Mart. }\end{array}$ \\
\hline $\begin{array}{l}\text { SERENUS/associated } \\
\text { phytotherapics }\end{array}$ & Coated tablet & $49.475 .833 / 0001-06$ & Valid & $\begin{array}{c}\text { Crataegus rhipidophylla Gand./Passiflora } \\
\text { incarnata L./Salix alba L. }\end{array}$ \\
\hline
\end{tabular}


TABLE 3: Continued.

\begin{tabular}{|c|c|c|c|c|}
\hline Product/category & Dosage form & Manufacturer Code & Status & Active \\
\hline $\begin{array}{l}\text { SINTOCALMY/simple herbal } \\
\text { simple anxiolytic }\end{array}$ & Coated tablet & $60.659 .463 / 0001-91$ & Valid & Passiflora incarnata $L$. \\
\hline SOMINEX/herbal compound & Tablet & $57.507 .378 / 0001-01$ & Canceled & $\begin{array}{l}\text { Crataegus rhipidophylla Gand./Valeriana } \\
\text { officinalis L./Passiflora incarnata L. }\end{array}$ \\
\hline $\begin{array}{l}\text { SOMINEX COMPOSTO/herbal } \\
\text { compound anxiolytics-drug } \\
\text { combinations }\end{array}$ & Coated tablet & $57.507 .378 / 0001-01$ & Canceled & $\begin{array}{c}\text { Valeriana officinalis L./Crataegus } \\
\text { rhipidophylla Gand./ Passiflora incarnata } \\
\text { L. }\end{array}$ \\
\hline SONOTABS/herbal compound & Simple dragee & $92.695 .691 / 0001-03$ & Canceled & $\begin{array}{l}\text { Passiflora dry extract/Salix dry extract/ } \\
\text { Crataegus rhipidophylla Gand. extract }\end{array}$ \\
\hline SONOTABS/herbal compound & Simple dragee & $90.455 .262 / 0001-33$ & Canceled & $\begin{array}{l}\text { Passiflora dry extract/Salix dry extract/ } \\
\text { Crataegus rhipidophylla Gand. extract } \\
\text { Aconitum napellus L./ Ammonium } \\
\text { bromatum/Agaricus muscarius/Citrullus } \\
\text { colocynthis Schrad./Colocynthis/ }\end{array}$ \\
\hline $\begin{array}{l}\text { SPASCUPREEL/potentized } \\
\text { compound }\end{array}$ & $\begin{array}{l}\text { Sublingual tablet/ } \\
\text { injectable solution }\end{array}$ & 05.994.539/0001-27 & Valid & $\begin{array}{l}\text { Gelsemium sempervirens (L.) J. St.-Hil./ } \\
\text { Magnesium phosphoricum/Matricaria } \\
\text { recutita L./ Passiflora incarnata L./ } \\
\text { Veratrum album L./ Atropinum } \\
\text { sulfuricum/Cuprum suphuricum }\end{array}$ \\
\hline $\begin{array}{l}\text { SPASCUPREEL/potentized } \\
\text { compound }\end{array}$ & Sublingual tablet/ & $74.455 .197 / 0001-90$ & Canceled & $\begin{array}{l}\text { Atropinum sulfuricum/Citrullus } \\
\text { colocynthis Schrad./Veratrum album L./ } \\
\text { Magnesium phosphoricum/Gelsemium } \\
\text { sempervirens (L.) J. St.-Hil./ Passiflora } \\
\text { incarnata L./ Agaricus muscarius/ } \\
\text { Chamomilla recutita/Aconitum napellus }\end{array}$ \\
\hline TENSART/simple herbal & Coated tablet/oral solution & $64.088 .172 / 0001-41$ & Canceled & Passiflora incarnata $L$ \\
\hline TENSART/ simple herbal & Coated tablet/oral solution & $17.440 .261 / 0001-25$ & Valid & Passiflora incarnata L. \\
\hline
\end{tabular}

Source: https://consultas.anvisa.gov.br/\#/medicamentos/. Accessed on December 03, 2019.

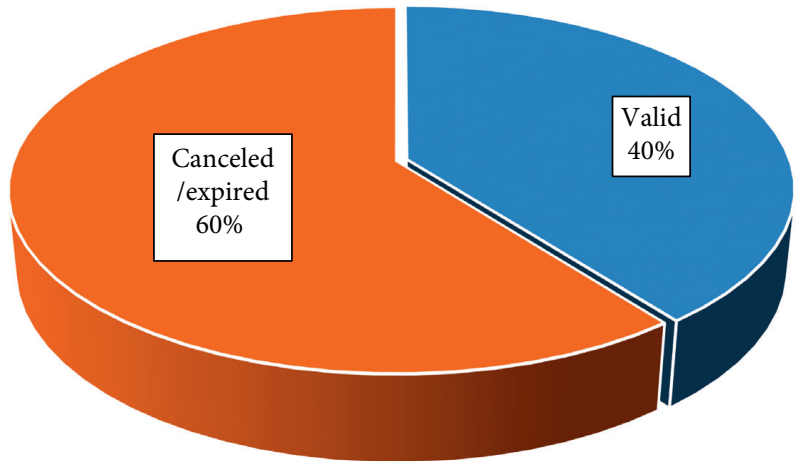

Figure 3: Valid and canceled/expired registrations of Passifloracontaining medicines registered in Brazil (ANVISA).

which is a folk preparation. Among the 86 products registered with ANVISA, Passiflora incarnata is present in $63 \%$ of them. Species of Passiflora genus are associated with other plant species in $57 \%$ of the products, in which P. incarnata predominates (Figure 4). Simple herbal medicines correspond to $43 \%$ of the total registered products, in which $P$. incarnata has been used in 30 registered products. The registration for the use of herbal products in association requires proof of the benefits of this composition, and a risk/ benefit evaluation [100], as well as the use of $P$. alata as a substituent of $P$. incarnata. Although $P$. alata is registered in the Brazilian Pharmacopoeia [19], this plant species is not listed in the normative rule about simplified registration of herbal medicines [77].

2.8. Patents and Registered Products Containing Passiflora outside Brazil. Outside Brazil, empirical searches carried out in the database of the United States Patent and Trademark Office, an Agency of the Department of Commerce North American, indicated the existence of 572, 164 and 4 patents when the keywords "passion flower", "Passiflora edulis" and "Passiflora alata" were used, respectively [106].

From 2006 to 2013, 27 traditional herbal products containing Passiflora were registered with the Medicines and Healthcare Products Regulatory Agency (MHRA) of the United Kingdom. All of them contain extracts of $P$. incarnata in single formulations or in association with other plant species. These associations represent approximately $74 \%$ of all the products, and include, in their formulations, species traditionally used to treat anxiety, such as Valeriana officinalis (Valerianaceae), Lactuca virosa (Asteraceae), 


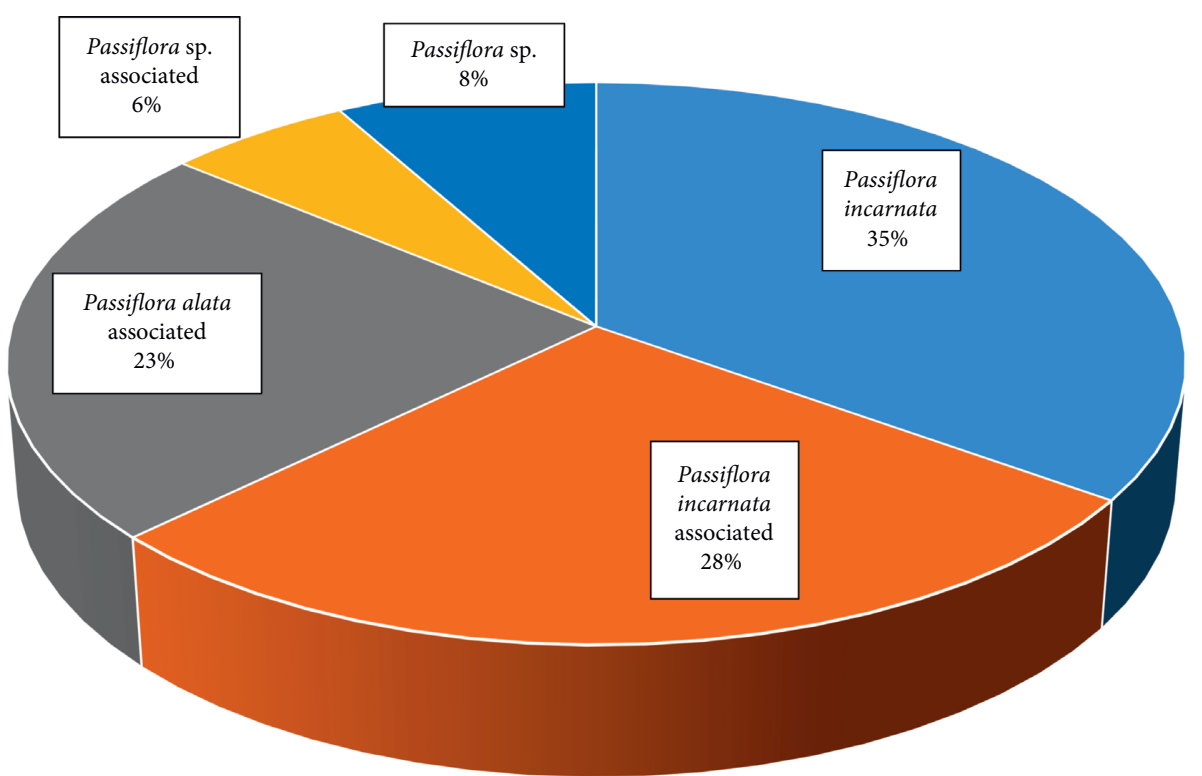

Figure 4: Distribution of Passiflora species in ANVISA registered products containing Passiflora sp.

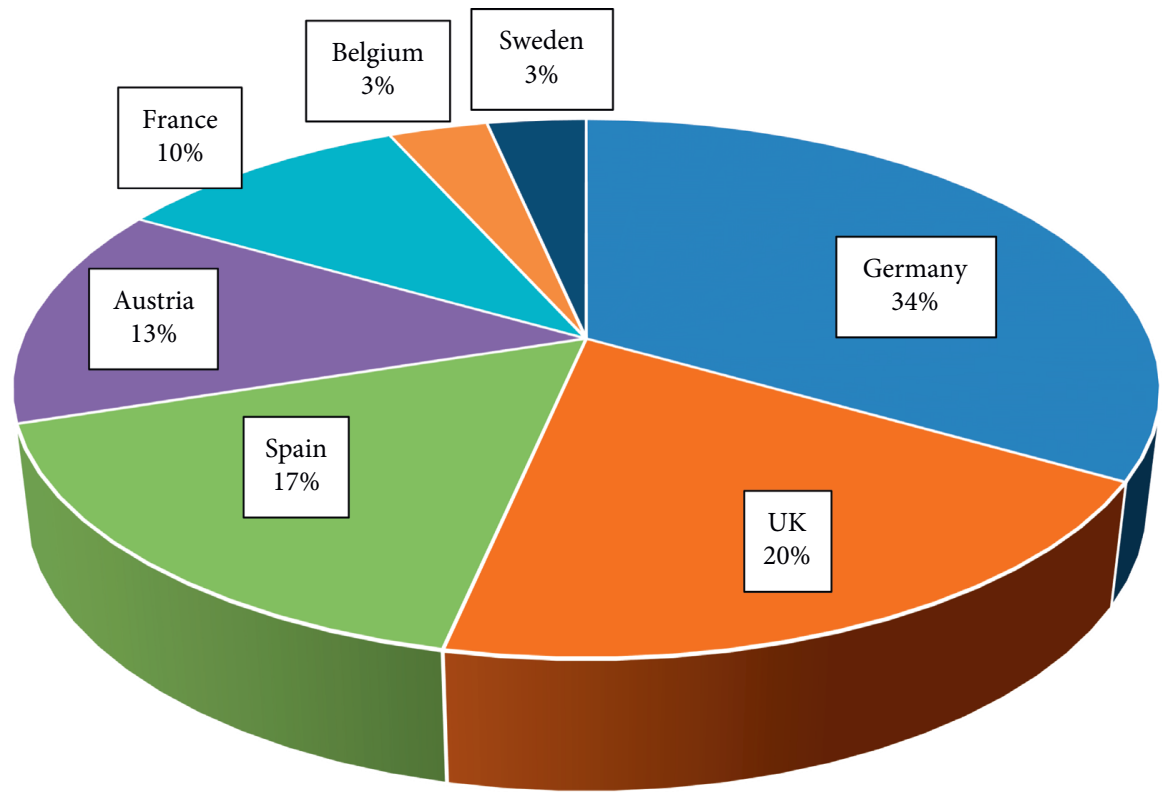

Figure 5: Distribution of preparations containing Passiflora incarnata registered in Europe Union, according to the European Medicines Agency [21].

Hypericum perforatum (Hypericaceae), and Melissa officinalis (Lamiaceae) [20].

According to the European Medicines Agency, affiliated to the European Union, various herbal preparations containing $P$. incarnata are used in the member countries, with marketing authorization and/or registrations for traditional use. Of the total of thirty preparations registered in Europe, Germany has ten, the UK six, Spain five, Austria four, France three, Belgium one, and Sweden one (Figure 5). The main uses are sachets containing fragmented plant material for use in herbal teas, simple or coated tablets containing dry ethanol extract, hard capsules with powdered or fragmented plant material or dry ethanol extract, instant products containing aqueous extract for the preparation of herbal tea, and liquid products for oral use containing ethanol liquid extract. All these preparations are indicated for the relief of symptoms of mild neurasthenia and for insomnia [21].

\section{Conclusions}

This work deals with the medicinal plants of the genus Passiflora that have effects on generalized anxiety disorders. Although it is the genus most used by humans for therapeutic purposes within the Passifloraceae family, especially for the treatment of phenomena related to the anxiety syndrome, it is still restricted to very few plant species. In 
Brazil, the registered and/or patented products containing extracts of Passiflora species only include a small number of taxa, highlighting $P$. incarnata and $P$. alata. Among the 86 registered products in Brazil as "Passiflora," those contain $P$. incarnata in single formulations or in combination with other ingredients represent $63 \%$ of the total, suggesting that this species of Passiflora genus is the most commonly used in medicines. In other countries, $P$. incarnata is also selected as the main component in natural anxiolytic drug formulations, with a long history of use and inclusion as an official plant drug in various Pharmacopoeias, since its effects are documented. Nevertheless, under the criteria of scientific knowledge about the pharmacological properties of Passiflora indicated in nonclinical and clinical studies that might be accompanied by the determination of the chemical composition of the extracts, formulations, and products, other studies are still needed to validate the mechanism of action and recognize the medicinal use of Passiflora species as well-established. What other species of Passiflora can be used safely in therapy as substituents of those most currently used? What are the criteria for this choice? These questions are important, considering that there are around 600 known species little or unexploited for medicinal purposes and that many of them are mainly distributed in tropical regions, such as Brazil. Therefore, research should be implemented immediately, in order to extend the herbal chain production and increase the commercial value of these products.

\section{Conflicts of Interest}

The authors declare that there are no conflicts of interest regarding the publication of this paper.

\section{Acknowledgments}

This research was financially supported by PROEP-CNPq (grant no. 407856/2017-0).

\section{References}

[1] E. A. Carlini, "Plants and the central nervous system," Pharmacology Biochemistry and Behavior, vol. 75, pp. 501512, 2003.

[2] K. Dhawan, S. Kumar, and A. Sharma, "Comparative anxiolytic activity profile of various preparations of Passiflora incarnata Linneaus: a comment on medicinal plants' standardization," Journal of Alternative and Complementary Medicine, vol. 8, no. 3, pp. 283-291, 2002.

[3] S. Wakdikar, "Global health care challenge: Indian experiences and new prescriptions," Electronic Journal of Biotechnoly, vol. 7, pp. 214-220, 2004.

[4] Germany, Federal Law Gazette [BGBl], "Medicinal products act, part I," vol. 12, p. 3394, 2005 Updated by Federal Law Gazette I, Law of October 19, 2012, p. 2192. http://www. gesetze-im-internet.de/englisch_amg/medicinal_products_ act.pdf.

[5] E Union and The European parliament and of the Council, Directive 2001/83/EC, Official Journal of the European Union, 2001, http://www.wipo.int/wipolex/en/text.jsp?file_ $\mathrm{id}=291864$.
[6] E Union and The European parliament and of the Council, Directive 2004/24/EC, Official Journal of the European Union, 2004, http://www.wipo.int/wipolex/en/text.jsp?file_ $\mathrm{id}=179078$.

[7] M. Miroddi, C. Mannucci, F. Mancari, M. Navarra, and G. Calapai, "Research and development for botanical products in medicinals and food supplements market," Evidence-Based Complementary Alternative Medicine, vol. 2013, Article ID 649720, 6 pages, 2013.

[8] Brazil, Ministry of Health and ANVISA, "RDC no 14/March 31, 2010," Diário Oficial da União, ANVISA, Brasilia, Brazil, 2010, http://portal.anvisa.gov.br/documents/10181/2718376/ RDC_14_2010_COMP.pdf/a919c09b-0717-451d-849b067153c02930? version $=1.0$.

[9] Brazil, Ministry of Health and ANVISA, "RDCN. 26/May 13, 2014," Diário Oficial da União, Brasilia, Section 1, pp. 52-58, ANVISA, Brasilia, Brazil, 2014, http://pesquisa.in.gov.br/ imprensa/jsp/visualiza/index.jsp? jornal=1\&pagina $=52 \&$ data $=14 / 05 / 2014$.

[10] S. F. Arifin, A. Al Shami, S. S. S. Omar, M. A. A. Jalil, K. A. Khalid, and H. Hadi, "Impact of modern technology on the development of natural-based products," Journal of Ayurvedic and Herbal Medicine, vol. 5, pp. 133-142, 2019.

[11] S.V. Scopus ${ }^{\circledR}$, Bibliographic Database and Search Site, Elsevier B.V., Amsterdam, Netherlands, 2019, http://www. scopus.com.

[12] Scirus ${ }^{\circledR}$, Bibliographic Database and Search Site, Elsevier B.V., Amsterdam, Netherlands, 2019, http://www.scirus. com.

[13] SciFinder ${ }^{\circledR}$, Bibliographic Database and Search Site, Chemical Abstracts Service, Columbus, OH, USA, 2019, http:// scifinder.cas.org/.

[14] Google Scholar ${ }^{\circledR}$, Search Site, Google LLC, Mountain View, CA, USA, 2019, https://scholar.google.com.br/.

[15] United States, Department of Health and Human Services and National Institutes of Health (NIH), Database. ClinicalTrials.Gov. National Institutes of Health (NIH), Bethesda, MA, USA, 2020, https://clinicaltrials.gov.

[16] Brazil, National Institute of Industrial Property (INPI), Search Website, National Institute of Industrial Property (INPI), Courbevoie, France, 2019, https://gru.inpi.gov.br/ pePI/servlet/PatenteServletController.

[17] Brazil, Ministry of Health and ANVISA, Datavisa ANVISA Websitae, Ministry of Health, Brazil, 2019, https://consultas. anvisa.gov.br/\#/medicamentos/.

[18] World Trade Organization, Agreement on Trade-Related Aspects of Intellectual Property Rights, World Trade Organization, Geneva, Switzerland, 1994, https://www.wto.org/ english/tratop_e/trips_e/t_agm1_e.htm.

[19] Brazil, Ministry of Health and ANVISA, Brazilian Pharmacopoeia, ANVISA, Brasilia, Brazil, PM061-PM062, 6th edition, 2019.

[20] MHRA (Medicines and Healthcare Products Regulatory Agency), Guidance: Herbal Medicines Granted a Traditional Herbal Registration, Medicines and Healthcare Products Regulatory Agency, London UK, 2014, https://www.gov.uk/ government/publications/herbal-medicines-granted-atraditional-herbal-registration-thr/herbal-medicinesgranted-a-traditional-herbal-registration.

[21] HMPC, Assessment Report on Passiflora Incarnata L. Herba, https://www.ema.europa.eu/en/documents/herbal-report/ final-assessment-report-passiflora-incarnata-1-herba_en.pdf EMA/HMPC/669738/2013, pp. 1-22, European Medicines Agency, Amsterdam, Netherlands, 2014, . 
[22] V. C. Muschner, A. P. Lorenz, A. C. Cervi, S. L. Bonatto, and T. T. Souza-Chies, "A first molecular phylogenetic analysis of Passiflora (Passifloraceae)," American Journal of Botany, vol. 8, pp. 1229-1238, 2003.

[23] T. Ulmer and J. M. Mac Dougal, Passiflora: Passionflowers of the World, Timber Press, Portland, OR, USA, 2004.

[24] C. A. M. Pereira and J. H. Y. Vilegas, "Constituintes químicos e farmacologia do gênero Passiflora com ênfase a $P$. alata Dryander," Revista Brasileira de Plantas Medicinais, vol. 3, pp. 1-12, 2000.

[25] M. M. Souza, T. N. S. Pereira, and M. C. Vieira, "Cytogenetic studies in some species of Passiflora L. (Passifloraceae): a review emphasizing Brazilian species," Brazilian Archives of Biology Technology, vol. 51, pp. 247-258, 2008.

[26] C. B. M. Cerqueira-Silva, L. D. H. C. S. Conceição, A. P. Souza, and R. X. Corrêa, "A history of passion fruit woodiness disease with emphasis on the current situation in Brazil and prospects for Brazilian passion fruit cultivation," European Journal of Plant Pathology, vol. 139, pp. 261-270, 2014.

[27] G. Gosmann, G. Provesnsi, L. N. Comunello, and S. M. K. Rates, "Composição química e aspectos farmacológicos de espécies de Passiflora L. (Passifloraceae)," Revista Brasileira de Biociencias, vol. 9, pp. 88-99, 2011.

[28] J. C. Oliveira and C. Ruggiero, "Espécies de Maracujá com potencial agronômico," in Maracujá germoplama e melhoramento genético, F. G. Faleiro, N. T. V. Junqueira, and M. F. Braga, Eds., pp. 141-158, Embrapa Cerrados, Planaltina, Brazil, 2005, http://www.cpac.embrapa.br/ivrtpm/ homepage/capitulos/cap_6.pdf.

[29] A. Braga, T. P. Medeiros, and B. V. Araújo, "Investigação da atividade antihiperglicemiante da farinha da casca de Passiflora edulis Sims, Passifloraceae, em ratos diabéticos induzidos por aloxano," Revista Brasileira de Farmacognosia, vol. 20, pp. 186-191, 2010.

[30] M. Miroddi, G. Calapai, M. Navarra, P. L. Minciullo, and S. Gangemi, "Passiflora incarnata L.: ethnopharmacology, clinical application, safety and evaluation of clinical trials," Journal of Ethnopharmacology, vol. 150, pp. 791-804, 2013.

[31] N. Klein, A. C. Gazola, T. C de Lima, E. Schenkel, K. Nieber, and V. Butterweck, "Assessment of sedative effects of Passiflora edulis f. flavicarpa and Passiflora alata extracts in mice, measured by telemetry," Phytotherapy Research, vol. 28, pp. 706-713, 2014.

[32] A. C. Cervi and W. A. Rodrigues, "Nomenclatural and taxonomic review of Passifloraceae species illustrated and described by Vellozo in Flora Fluminensis," Acta Botanica Brasilica, vol. 24, pp. 1109-1111, 2010.

[33] K. Dhawan, S. Dhawan, and A. Sharma, "Passiflora: a review update," Journal of Ethnopharmacololy, vol. 94, pp. 1-23, 2004.

[34] F. De-Paris, R. D. Petry, F. H. Reginatto et al., "Pharmacochemical study of aqueous extract of Passiflora alata Dryander and Passiflora edulis Sims," Acta Farmaceutica Bonaerense, vol. 21, pp. 5-8, 2002.

[35] R. Soulimani, C. Younos, S. Jarmouni, D. Bousta, R. Misslin, and F. Mortier, "Behavioural effects of Passiflora incarnata L. and its indole alkaloid and flavonoid derivatives and maltol in the mouse," Journal of Ethnopharmacology, vol. 57, pp. 11-20, 1997.

[36] M. S. Oliveira, I. O. Pinheiro, and F. S. B. V. Silva, "Vermicompost and arbuscular mycorrhizal fungi: an alternative to increase foliar orientin and vitexin-2-O-ramnoside synthesis in Passiflora alata Curtis seedlings," Industrial Crops and Products, vol. 77, pp. 754-757, 2015.

[37] A. Rehwald, B. Meier, and O. Sticher, "Qualitative and quantitative reversed-phase high-performance liquid chromatography of flavonoids in Passiflora incarnata L," Pharmaceutica Acta Helvetiae, vol. 69, pp. 153-158, 1994.

[38] S. V. F. Gomes, L. A. Portugal, J. P. Anjos et al., "Accelerated solvent extraction of phenolic compounds exploiting a BoxBehnken design and quantification of five flavonoids by HPLC-DAD in Passiflora species," Microchemical Journal, vol. 132, pp. 28-35, 2017.

[39] S. M. Zucolotto, C. Fagundes, F. H. Reginatto et al., "Analysis of C-glycosyl flavonoids from south American Passiflora species by HPLC-DAD and HPLC-MS," Phytochemical Analysis, vol. 23, pp. 232-239, 2012.

[40] A. Ulubelen, S. Oksuz, T. J. Mabry, G. Dellamonica, and J. Chopin, "C-glycosylflavonoids from Passiflora pittieri, $P$. alata, P. ambigua and Adenia mannii," Journal of Natural Products, vol. 45, p. 783, 1982.

[41] M. A. Farag, A. Otify, A. Porzel, C. G. Michel, A. Elsayed, and L. A. Wessjohann, "Comparative metabolite profiling and fingerprinting of genus Passiflora leaves using a multiplex approach of UPLC-NS and NMR analysed by chemometric tools," Analytical and Bioanalytical Chemistry, vol. 408, pp. 3125-3143, 2016.

[42] L. Wosch, K. C. Santos, and D. C. Imig, "Comparative study of Passiflora taxa leaves: II. A chromatographic profile," Brazilian Journal Pharmacognosy, vol. 27, pp. 40-49, 2017.

[43] C. L. Lin, C. L. Kao, S. C. Huang et al., "Chemical constituents of fruit shells of Passiflora edulis," Chemistry Natural Compounds, vol. 52, pp. 314-315, 2016.

[44] Y. Hu, L. Jiao, M. H. Jiang et al., "A new C-glycosyl flavone and a new neolignan glycoside from Passiflora edulis Sims peel," Natural Products Research, vol. 32, pp. 2312-2318, 2018.

[45] R. D. Petry, K. C. B. De Souza, V. L. Bassani, P. R. Petrovick, and G. G. Ortega, "Doseamento do teor de flavonóides totais em extratos em extratos hidroalcóolicos de Passiflora alata Dryander (maracujá)," Revista Brasileira de Farmácia, vol. 79, pp. 7-10, 1998.

[46] R. D. Petry, F. Reginatto, F. De-Paris et al., "Comparative pharmacological study of hydroethanol extracts of Passiflora alata and Passiflora edulis leaves," Phytotherapy Research, vol. 15, pp. 162-164, 2001.

[47] S. D. Müller, S. B. Vasconcelos, M. Coelho, and M. V. Biavatti, "LC and UV determination of flavonoids from: Passiflora alata medicinal extracts and leaves," Journal of Pharmaceutical and Biomedical Analysis, vol. 37, pp. 399-403, 2005.

[48] C. A. M. Pereira, J. H. Yariwake, F. M. Lanças, J. N. Wauters, M. Tits, and L. Angenot, "A HPTLC densitometric determination of flavonoids from Passiflora alata, P. edulis, P. incarnata and $P$. caerulea and comparison with HPLC method," Phytochemical Analysis, vol. 15, pp. 241-248, 2004.

[49] F. Reginatto, H. F. De-Paris, R. D. Petry et al., "Evaluation of anxiolytic activity of spray dried powders of two South Brazilian Passiflora species," Phytotherapy Research, vol. 20, pp. 348-351, 2006.

[50] G. Gonzáles Ortega and P. C. Schmidt, "Stability studies on dried extracts of passion flower (Passiflora incarnata L.)," Pharma Sciences, vol. 5, pp. 385-389, 1995.

[51] V. Quercia, L. Turchetto, N. Pierini, V. Cuozzo, and G. Percaccio, "Identification and determination of vitexin 
and isovitexin in Passiflora incarnata extracts," Journal of Chromatograph A, vol. 161, pp. 396-402, 1978.

[52] M. Jay, "C-glycosylflavonoids," in The Flavonoids, J. B. Harbone, Ed., Chapman \& Hall, London, UK, 1996.

[53] H. Wohlmuth, K. G. Penman, T. Pearson, and R. P. Lehmann, "Pharmacognosy and chemotypes of passionflower (Passiflora incarnata L.)," Biological and Pharmaceutical Bulletin, vol. 33, pp. 1015-1018, 2010.

[54] M. L. Zeraik, C. A. M. Pereira, V. G. Zuin, J. H. Yariwake, and Maracujá, "Um alimento funcional?" Revista Brasileira de Farmacognosia, vol. 20, pp. 459-471, 2010.

[55] J. B. Harbone and H. Baxter, Phytochemical Dictionary: A Handbook of Bioactive Compound from: Plants, Taylor \& Francis, London, UK, 1995.

[56] J. Lutomski and T. Wrocinski, "Pharmacodinamic properties of $P$. incarnata preparations. The effect of alkaloid and flavonoid components on pharmacodinamic properties of the raw materials," Biuletyn Instytutu Roslin Leczniczych, vol. 6, pp. 176-184, 1960.

[57] WHO and H. Passiflorae, WHO Monographs on Selected Medicinal Plants, pp. 257-267, World Health Organization Press, Geneva, Switzerland, 2007.

[58] C. Wasowski and M. Marder, "Flavonoids as $\mathrm{GABA}_{\mathrm{A}}$ receptor ligands: the whole story?" Journal of Experimental Pharmacology, vol. 4, pp. 9-24, 2012.

[59] F. Wang, M. S. Y. Huen, S. Y. Tsang, and H. Xue, "Neuroactive flavonoids interacting with $\mathrm{GABA}_{\mathrm{A}}$ receptor complex," Current Drug Targets, vol. 4, pp. 575-585, 2005.

[60] W. Zhang, K. F. Koehler, P. Zhang, and J. M. Cook, "Development of a comprehensive pharmacophore model for the benzodiazepine receptor," Drug Design and Discovery, vol. 12, pp. 193-248, 1995.

[61] J. R. Hanrahan, M. Chebib, and G. A. R. Johnston, "Flavonoid modulation of $\mathrm{GABA}_{\mathrm{A}}$ receptors," British Journal of Pharmacology, vol. 163, pp. 234-245, 2011.

[62] K. Dekermendjian, P. Kahnberg, M. R. Witt, O. Sterner, M. Nielsen, and T. Liljefors, "Structure-activity relationships and molecular modeling analysis of flavonoids binding to the benzodiazepine site of the rat brain $\mathrm{GABA}_{\mathrm{A}}$ receptor complex," Journal of Medicinal Chemistry, vol. 42, pp. 4343-4350, 1999.

[63] X. Huang, T. Liu, J. Gu et al., "3D-QSAR Model of flavonoids binding at benzodiazepine site in $\mathrm{GABA}_{\mathrm{A}}$ receptors," Journal of Medicinal Chemistry, vol. 44, pp. 1883-1891, 2001.

[64] P. Kahnberg, E. Lager, C. Rosenberg et al., "Refinement and evaluation of a pharmacophore model for flavone derivatives binding to the benzodiazepine site of the $\mathrm{GABA}_{\mathrm{A}}$ receptor," Journal of Medicinal Chemistry, vol. 45, pp. 4188-4201, 2002.

[65] D. K. R. Holanda, N. J. Wurlitzer, A. P. Dionisio et al., "Garlic passion fruit (Passiflora tenuifila Killip): assessment of eventual acute toxicity, anxiolytic, sedative, and anticonvulsant effects using in vivo assays," Food Research International, vol. 128, Article ID 108813, 2020.

[66] J. Zhang, Y. He, X. Jiang, H. Jiang, and J. Shen, "Nature brings new avenues to the therapy of central nervous system diseases-an overview of possible treatments derived from natural products," Science China Life Sciences, vol. 62, no. 10, pp. 1332-1367, 2019.

[67] L. J. Germán-Ponciano, A. Puga-Olguín, M. J. RovirosaHernández, M. Caba, E. Meza, and J. F. Rodríguez-Landa, "Differential effects of acute and chronic treatment with the flavonoid chrysin on anxiety-like behavior and fos immunoreactivity in the lateral septal nucleus in rat," Acta Pharmaceutica, vol. 70, pp. 387-397, 2020.
[68] J. S. F. Alves, J. L. Marques, D. P. Demarque et al., "Involvement of isoorientin in the antidepressant bioactivity of a flavonoid-rich extract from Passiflora edulis f. flavicarpa leaves," Revista Brasileira de Farmacognosia, vol. 30, pp. 240-250, 2020.

[69] M. Rashno, S. Ghaderi, A. Nesari, L. Khoesandi, Y. Farbood, and A. Sarkaki, "Chrysin attenuates traumatic brain injuryinduced recognition memory decline, and anxiety/depression-like behaviors in rats: insights into underlying mechanisms," Psychopharmacology, vol. 237, pp. 1607-1619, 2020.

[70] K. Appel, T. Rose, B. Fiebich, T. Kammler, C. Hoffmann, and G. Weiss, "Modulation of the $\gamma$-aminobutyric acid (GABA) system by Passiflora incarnata L," Phytotherapy Research, vol. 25, pp. 838-843, 2011, https://onlinelibrary.wiley.com/ doi/epdf/10.1002/ptr.3352.

[71] H. Viola, C. Wasowski, M. L. Stein et al., "Apigenin, a component of Matricaria recutita flowers, is a central benzodiazepine receptors-ligand with anxiolytic effects," Planta Medica, vol. 61, pp. 213-216, 1995.

[72] C. Vissiennona, K. Nieber, O. Kelber, and V. Butterweck, "Route of administration determines the anxiolytic activity of the flavonols kaempferol, quercetin and myricetin-are they prodrugs?" The Journal of Nutritional Biochemistry, vol. 23, pp. 733-774, 2012.

[73] C. Braestrup, M. Nielsen, and C. E. Olsen, "Urinary and brain $\beta$-carboline-3-carboxylates as potent inhibitors of brain benzodiazepine receptors," Proceedings of the National Academy of Sciences of the United States of America, vol. 77, pp. 2288-2292, 1980.

[74] S. S. Bharate, S. Mignani, and R. A. Vishwakarma, "Why are the majority of active compounds in the CNS domain natural products? A critical analysis," Journal of Medicinal Chemistry, vol. 61, pp. 10345-10374, 2018.

[75] S. Salerno, F. Settimo, S. Taliani et al., "Medicinal chemistry of indolylglyoxylamide $\mathrm{GABA}_{\mathrm{A}} / \mathrm{BzR}$ high affinity ligands: identification of novel anxiolytic/non sedative agents," Current Topics in Medicinal Chemistry, vol. 12, pp. 286-311, 2012.

[76] T. Clayton, M. M. Poe, S. Rallapalli et al., "A review of the updated pharmacophore for the alpha $5 \mathrm{GABA}(\mathrm{A})$ benzodiazepine receptor model," International Journal of Medicinal Chemistry, vol. 2015, Article ID 430248, 54 pages, 2015.

[77] Brazil, Ministry of Health and ANVISA, "Normative instruction n. 2./May 13, 2014," Diário Oficial da União, Brasilia, Section 1, pp. 58-61, ANVISA, Brasilia, Brazil, 2014, http://pesquisa.in.gov.br/imprensa/jsp/visualiza/index.jsp? data $=14 / 05 /$

2014\&jornal=1 \&pagina $=58$ \&totalArquivos $=100$.

[78] Brazil, Ministry of Health and ANVISA, Monografia da espécie Passiflora incarnata Linnaeus (maracujá-vermelho), ANVISA, Brasilia, Brazil, 2015, https://www.saude.gov.br/ images/pdf/2016/fevereiro/05/Monografia-Passifloraincarnata.pdf.

[79] R. C. Fierascu, I. Fierascu, A. Ortan, M. I. Georgiew, and E. Sieniawska, "Innovative approaches for recovery of phytoconstituents from medicinal/aromatic plants and biotechnological production," Molecules, vol. 25, no. 2, p. 309, 2020.

[80] S. M. He, E. Chan, and S. F. Zhou, "ADME Properties of herbal medicines in humans: evidence, challenges and strategies," Current Pharmaceutical Design, vol. 17, pp. 357-407, 2011.

[81] C. Huang, C. Zheng, Y. Li, Y. Wang, A. Lu, and L. Yang, "Systems pharmacology in drug discovery and therapeutic 
insight for herbal medicines," Briefings in Bioinformatics, vol. 15, pp. 710-733, 2013.

[82] S. Sut, V. Baldan, M. Faggian, G. Peron, and S. Dall'Acqua, "Nutraceuticals, a new challenge for medicinal chemistry," Current Medicinal Chemistry, vol. 23, pp. 1-26, 2016.

[83] M. Rasool, A. Malik, S. Waquar et al., "In-Silico characterization and in-vivo validation of Albizia saponin-A, isoorientin, and aalvadorin using a rat model of Alzheimer's disease," Frontiers in Pharmacology, vol. 9, pp. 99-113, 2018.

[84] M. Wang, J. Firrman, L. Liu, and K. Yam, "A review on flavonoid apigenin: dietary intake, ADME, antimicrobial effects, and interactions with human gut microbiota," BioMed Research International, vol. 2019, Article ID 7010467, 18 pages, 2019.

[85] M. U. Mirza, N.-Ul-H. Ghori, N. Ikram, A. R. Adil, and S. Manzoor, "Pharmacoinformatics approach for investigation of alternative potential hepatitis $\mathrm{C}$ virus nonstructural protein 5B inhibitors," Drug Design, Development and Therapy, vol. 9, pp. 1825-1841, 2015.

[86] M. H. Abraham, "The factors that influence permeation across the blood-brain barrier," European Journal of Medicinal Chemistry, vol. 39, pp. 235-240, 2004.

[87] S. M. Stamatovic, R. F. Keep, and A. V. Andjelkovic, "Brain endothelial cell-cell junctions: how to "open" the blood brain barrier," Current Neuropharmacology, vol. 6, pp. 179-192, 2008.

[88] R. Ancuceanu, M. Dinu, C. Dinu-Pirvu, V. Anuta, and V. Negulescu, "Pharmacokinetics of B-ring unsubstituted flavones," Pharmaceutics, vol. 11, p. 370, 2019.

[89] K. Noh, D. G. Oh, M. R. Nepal et al., "Pharmacokinetic interaction of chrysin with caffeine in rats," Biomolecules \& Therapeutics, vol. 24, no. 4, pp. 446-452, 2016.

[90] A. F. G. Cicero and A. Colletti, "Handbook of Nutraceuticals for Chemical Use," in Nutraceuticals Active on Central Nervous System, pp. 1-23, Springer International Publishing AG, Cham, Switzerland, 2018.

[91] A. Mori, K. Hasegawa, M. Murasaki et al., "Clinical evaluation of Passiflamin (Passiflora extract) on neurosis-multicenter double blind study in comparison with mexazolam," Clinical Evaluation, vol. 21, pp. 383-440, 1993.

[92] L. S. Miyasaka, Á. N. Atallah, and B. Soares, "Passiflora for Anxiety Disorder," Cochrane Database of Systematic Reviews Issue 1. Art. No CD004518, Cochrane, London, UK. https://www. cochranelibrary.com/cdsr/doi/10.1002/14651858.CD004518. pub2/full, 2007.

[93] S. Akhondzadeh, H. R. Naghavi, M. Vazirian, A. Shayeganpour, and M. Khani, "Passionflower in the treatment of generalized anxiety: a pilot double-blind randomized controlled trial with oxazepam," Journal of Clinical Pharmacy and Therapeutics, vol. 26, pp. 363-367, 2001.

[94] S. Akhondzadeh, L. Kashani, M. Mobaseri, S. H. Hosseini, S. Nikzad, and M. Khani, "Passionflower in the treatment of opiates withdrawal: a double-blind randomized controlled trial," Journal of Clinical Pharmacy and Therapeutics, vol. 26, pp. 369-373, 2001.

[95] A. Movafegh, R. Alizadeh, F. Hajimohamadi, F. Esfehani, and M. Nejatfar, "Preoperative oral Passiflora incarnata reduces anxiety in ambulatory surgery patients: a doubleblind, placebo-controlled study," Anesthesis \& Analgesia, vol. 106, pp. 1728-1732, 2008.

[96] P. Aslanargun, O. Cuvas, B. Dikmen, E. Aslan, and M. U. Yuksel, "Passiflora incarnata Linneaus as an anxiolytic before spinal anesthesia," Journal of Anesthesia, vol. 26, pp. 39-44, 2012.
[97] L. P. Dantas, A. Oliveira-Ribeiro, L. M. Almeida-Souza, and F. C. Groppo, "Effects of Passiflora incarnata and midazolam for control of anxiety in patients undergoing dental extraction," Medicina Oral, Patologia Oral y Cirurgia Bucal, vol. 22, pp. e95-101, 2017.

[98] A. Ngan and R. Conduit, "A double-blind, placebo-controlled investigation of the effects of Passiflora incarnata (passionflower) herbal tea on subjective sleep quality," Phytotherapy Research, vol. 25, pp. 1153-1159, 2011.

[99] Brazil, Presidency of the Republic and National Congress, "Law No. 9.279/May 14, 1996," Diário Oficial da União, Brasilia, Section 1, http://www.planalto.gov.br/ccivil_03/leis/ L9279.htm, p. 8353, National Congress, Brasília, Brazil, 1996,

[100] Brazil, Presidency of the Republic, "Decree No 5.813/June 22, 2006," Diário Oficial da União, Brasilia, Section 1, http:// www.planalto.gov.br/ccivil_03/_ato2004-2006/2006/ decreto/d5813.htm, p. 2, National Congress, Brasília, Brazil, 2006, .

[101] A. C. Muller and M. F. Macedo, "Patentes de fitomedicamentos: como garantir o compartilhamento dos benefícios de P \& D e do uso sustentável de recursos genéticos," Revista Fitos, vol. 1, no. 2, pp. 19-24, 2005.

[102] Brazil, Presidency of the Republic and National Congress, "Law No 9.782/January 26, 1999," Diário Oficial da União, Brasilia, Section 1, http://www.anvisa.gov.br/legis/ consolidada/lei_9782_99.pdf, p. 1, National Congress, Brasília, Brazil, 1999, .

[103] Brazil, Ministry of Health and ANVISA, "RDC No 38/June 18, 2014," Diário Oficial da União, Brasilia, Section 1, pp. 58-61, ANVISA, Brasilia, Brazil, 2014, http://bvsms. saude.gov.br/bvs/saudelegis/anvisa/2014/rdc0038_18_06_ 2014.pdfhttp://bvsms.saude.gov.br/bvs/saudelegis/anvisa/ 2014/rdc0038_18_06_2014.pdfhttp://bvsms.saude.gov.br/ bvs/saudelegis/anvisa/2014/rdc0038_18_06_2014.pdf.

[104] Brazil, Ministry of Health and ANVISA, "RDC 66/November 26, 2014," Diário Oficial da União, Brasilia, Section 1, pp. 46-47, ANVISA, Brasilia, Brazil, 2014, http://pesquisa.in. gov.br/imprensa/jsp/visualiza/index.jsp? jornal $=1$ \&pagina $=46 \&$ data $=27 / 11 / 2014$.

[105] Brazil, Ministry of Health and ANVISA, "RDC 105/August 31, 2016," Diário Oficial da União, Brasilia, Section 1, pp. 47-48, ANVISA, Brasilia, Brazil, 2016, http://pesquisa.in. gov.br/imprensa/jsp/visualiza/index.jsp? jornal $=1$ \&pagina $=47 \&$ data $=01 / 09 / 2016$.

[106] United States and Department of Commerce; United States Patent and Trademark Office, "Patent full-text databases," 2019, http://patft.uspto.gov/netahtml/PTO/search-bool.html US Patent. 